Argonne

\title{
Vehicle Technologies Office Research and Development Program, Prospective Benefits Assessment Report for FY 2020
}

Energy Systems Division 


\begin{abstract}
About Argonne National Laboratory
Argonne is a U.S. Department of Energy laboratory managed by UChicago Argonne, LLC under contract DE-AC02-06CH11357. The Laboratory's main facility is outside Chicago,

at 9700 South Cass Avenue, Lemont, Illinois 60439. For information about Argonne

and its pioneering science and technology programs, see www.anl.gov.
\end{abstract}

\title{
DOCUMENT AVAILABILITY
}

Online Access: U.S. Department of Energy (DOE) reports produced after 1991 and a growing number of pre-1991 documents are available free at OSTI.GOV (http://www.osti.gov/),

a service of the US Dept. of Energy's Office of Scientific and Technical Information.

Reports not in digital format may be purchased by the public from the National Technical Information Service (NTIS):

U.S. Department of Commerce

National Technical Information Service

5301 Shawnee Road

Alexandria, VA 22312

www.ntis.gov

Phone: (800) 553-NTIS (6847) or (703) 605-6000

Fax: (703) 605-6900

Email: orders@ntis.gov

Reports not in digital format are available to DOE and DOE contractors from the Office of Scientific and Technical Information (OSTI):

U.S. Department of Energy

Office of Scientific and Technical Information

P.O. Box 62

Oak Ridge, TN 37831-0062

www.osti.gov

Phone: (865) 576-8401

Fax: (865) 576-5728

Email: reports@osti.gov

\footnotetext{
Disclaimer

This report was prepared as an account of work sponsored by an agency of the United States Government. Neither the United States Government nor any agency thereof, nor UChicago Argonne, LLC, nor any of their employees or officers, makes any warranty, express or implied, or assumes any legal liability or responsibility for the accuracy, completeness, or usefulness of any information, apparatus, product, or process disclosed, or represents that its use would not infringe privately owned rights. Reference herein to any specific commercial product, process, or service by trade name, trademark, manufacturer, or otherwise, does not necessarily constitute or imply its endorsement, recommendation, or favoring by the United States Government or any agency thereof. The views and opinions of document authors expressed herein do not necessarily state or reflect those of the United States Government or any agency thereof, Argonne National Laboratory, or UChicago Argonne, LLC.
} 


\section{Vehicle Technologies Office Research and Development Program, Prospective Benefits Assessment Report for FY 2020}

by

T.S. Stephens ${ }^{1}$, A. Birky², M. Dwyer ${ }^{3}$

${ }^{1}$ Energy Systems Division, Argonne National Laboratory

${ }^{2}$ National Renewable Energy Laboratory

${ }^{3}$ Energetics Incorporated

October 2020 



\section{CONTENTS}

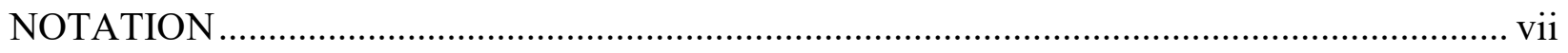

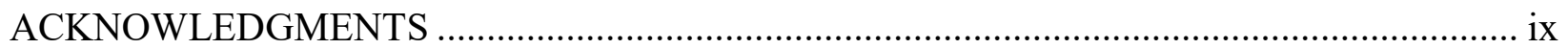

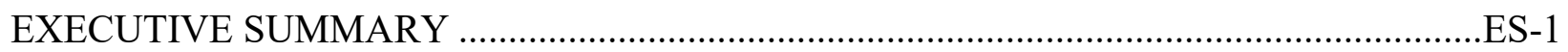

1 INTRODUCTION AND PROGRAM OVERVIEW .........................................................

1.1 Office of Energy Efficiency and Renewable Energy Sustainable Transportation

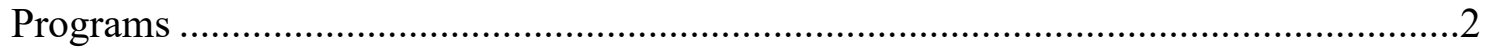

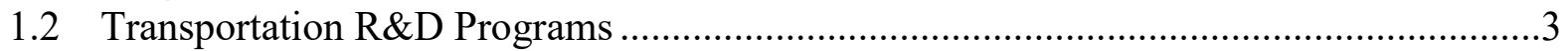

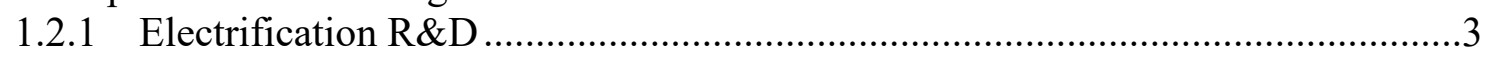

1.2.2 Advanced Combustion Systems and Fuels R\&D ............................................

1.2.3 Materials Technology R\&D ......................................................................

2 TRANSLATING PROGRAM GOALS INTO MODEL INPUT ….......................................5

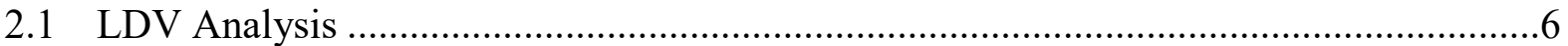

2.1.1 LDV Attributes .................................................................................... 6

2.1.2 LDV Market Penetration and On-road Stock Modeling .................................. 7

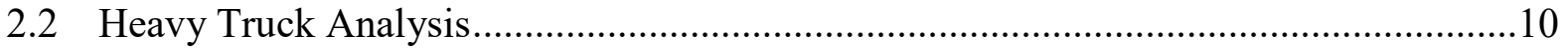

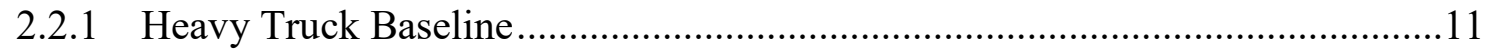

2.2.2 Heavy-truck Advanced Technology Modeling.................................................. 12

2.2.3 Heavy-truck Market Penetration and Stock Modeling .....................................12

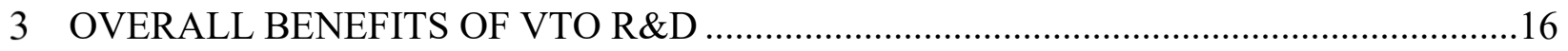

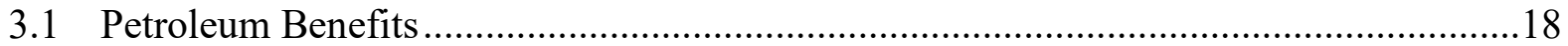

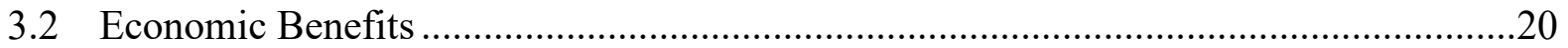

3.2.1 Consumer Fuel Economy.......................................................................20

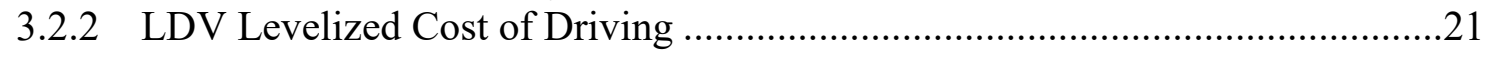

3.2.3 National-Level Vehicle Expenditures.............................................................23

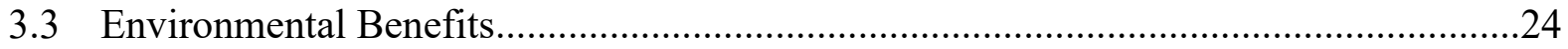

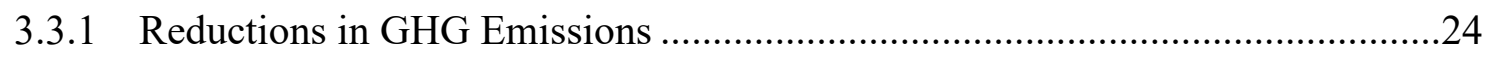

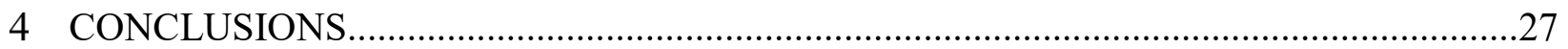

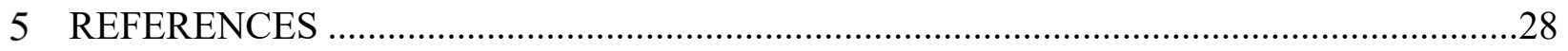

Appendix A: $\quad$ LIGHT-DUTY VEHICLE MODEL INPUTS AND OUTPUTS .......................32

A.1 Inputs of Light-Duty Vehicle (LDV) Vehicle Choice Modeling.................................32

A.2 Comparison of LDV Market Penetration.....................................................................33

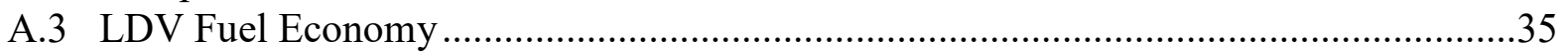

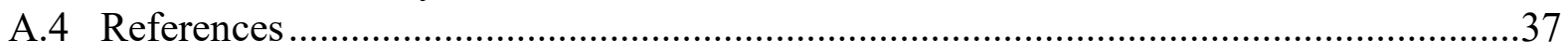




\section{CONTENTS (CONT.)}

Appendix B: HEAVY-TRUCK MARKET-PENETRATION MODELING...........................39

B.1 Heavy-Truck Market Penetration; PROGRAM SUCCESS SCENARIO ......................39

B.2 Heavy-Truck Market-Penetration Side Case ........................................................44

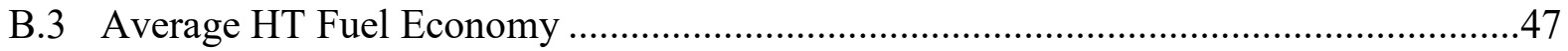

\section{FIGURES}

ES-1 Estimated On-road Petroleum Consumption under the No Program and Program Success Cases in 2035 and 2050, and Estimated Cumulative Petroleum Savings Attributed to Advancement in VTO- and Hydrogen and Fuel Cell Technologies Office-funded Technologies

ES-2 Fleet-averaged Fuel Efficiency through 2050 for Light-duty Vehicles and Class 3-8 Trucks for the Program Success and No Program Cases

ES-3 Difference in Annual National Consumer Costs of Vehicle Purchases and Fuel Costs for On-road Vehicles through 2050 between the No Program and Program Success Cases

1-1 General Approach and Information Flow in the Benefits Analysis..................................2

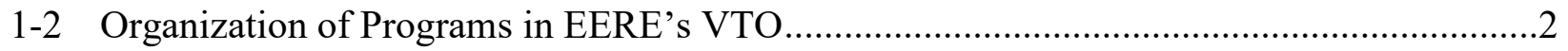

2-1 Fuel Prices Assumed for LDV Analysis .................................................................

2-2 Availability of Hydrogen Assumed for LDV Analysis ....................................................9

2-3 Fuel Prices Assumed for Diesel and Electricity in the HT Analysis ................................14

3-1 On-road Fuel Consumption by Fuel Type through 2050 for the Program Success and No Program Cases.

3-2 Estimated On-road Petroleum Consumption under the No Program and Program Success Cases in 2035 and 2050 and Estimated Cumulative Petroleum Savings Attributed to VTO Technology Programs

3-3 Fleet-averaged Fuel Efficiency through 2050 for LDVs and HTs for the Program Success and No Program Cases

3-4 Estimated Levelized Cost of Driving a 2025 Midsize Car for Five Years ........................22

3-5 Estimated Levelized Cost of Driving a 2035 Midsize Car for Five Years ........................22 


\section{FIGURES (CONT.)}

3-6 Differences in Annual National Consumer Expenditures for Vehicle Purchases and Fuel for LDVs through 2050 between the No Program and Program Success Cases

3-7 Differences in Annual National Costs of Vehicle Purchases and Fuel for HTs through 2050 between the No Program and Program Success Cases.

3-8 Estimated GHG Emissions under the No Program and Program Success Cases in 2035 and 2050 and Estimated Cumulative GHG Reductions Attributed to VTO Technology Programs after 2020 .25

A-1 Fuel Prices Used for Modeling, in 2015\$ per gge 33

A-2 LDV Stock by Powertrain Type for the No Program and Program Success Cases Modeled Using the $\mathrm{MA}^{3} \mathrm{~T}$ Model

A-3 LDV Stock by Powertrain Type for the No Program and Program Success Cases Modeled Using the ParaChoice Model.....

A-4 Fleet-averaged Fuel Economies of New LDVs for the No Program and Program Success Cases Based on Market Adoption Results from the Two LDV Choice Models

A-5 Average Fuel Economies of On-road LDVs for the No Program and Program Success Cases Based on Market Adoption Results from the Two LDV Choice Models

B-1 Estimated Shares of VMT by New Class 8 Sleeper Cab Trucks by Powertrain Type for the Program Success Case.

B-2 Estimated Shares of VMT by New Class $7 \& 8$ Day-cab Trucks by Powertrain Type for the Program Success Case.

B-3 Estimated Shares of VMT by New Class 7\&8 Vocational Vehicles by Powertrain Type for the Program Success Case

B-4 Estimated Shares of VMT by New Class 4-6 Vocational Vehicles by Powertrain Type for the Program Success Case

B-5 Estimated Shares of VMT by New (a) Class 8 Sleeper-cab Trucks, (b) Class 7\&8 Day-cab Trucks, (c) Class 7\&8 Single-unit Vocational Trucks, and (d) Class 4-6 Vocational Vehicles, for the Side Case Assuming No Constraints from Fuel Availability.

B-6 Fleet-averaged Fuel Economy of New HTs for the No Program and Program Success Cases 


\section{FIGURES (CONT.)}

B-7 Increase in New-fleet Fuel Economy, Program Success Case vs. No Program Case

B-8 Average Fuel Economy of On-road Stock of HTs for the No Program and Program Success Cases

\section{TABLES}

2-1 GHG Intensities of Electricity in the Default and High-renewables Electricity and Hydrogen Pathways

2-2 GHG Intensities of Hydrogen in the Default and High-renewables Electricity and Hydrogen Pathway Mixes.....

2-3 Powertrains Used in each Vehicle Class/Type Market in the TRUCK Model.

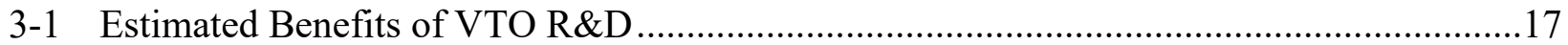

A-1 LDV Market-penetration Estimates for the No Program and Program Success Cases from the $\mathrm{MA}^{3} \mathrm{~T}$ Model.

A-2 LDV Market-penetration Estimates for the No Program and Program Success Cases from the ParaChoice Model

B-1 HT Market-penetration Estimates for the Program Success Case, as Percentage of VMT by New Vehicles

B-2 HT Market-penetration Estimates for the Program Success Case, as Percentage of New-vehicle Sales

B-3 HT Market-penetration Estimates for the Full Fuel Availability Side Case, as Percentage of VMT by New Vehicles

B-4 HT Market-penetration Estimates for the Full Fuel Availability Side Case, as Percentage of New-vehicle Sales 


\section{NOTATION}

\section{ACRONYMS AND INITIALISMS}

\begin{tabular}{|c|c|}
\hline 21CTP & $21^{\text {st }}$-Century Truck Partnership \\
\hline $\mathrm{AEO}$ & Annual Energy Outlook \\
\hline Argonne & Argonne National Laboratory \\
\hline $\begin{array}{l}\text { BETO } \\
\text { BEV }\end{array}$ & $\begin{array}{l}\text { Bioenergy Technologies Office } \\
\text { battery electric vehicle }\end{array}$ \\
\hline $\begin{array}{l}\mathrm{CI} \\
\mathrm{CO}_{2-\mathrm{eq}} \\
\mathrm{Conv}\end{array}$ & $\begin{array}{l}\text { compression-ignition } \\
\text { carbon dioxide equivalent } \\
\text { conventional }\end{array}$ \\
\hline DOE & U.S. Department of Energy \\
\hline $\begin{array}{l}\text { EERE } \\
\text { EIA } \\
\text { EPA }\end{array}$ & $\begin{array}{l}\text { Office of Energy Efficiency and Renewable Energy } \\
\text { Energy Information Administration } \\
\text { U.S. Environmental Protection Agency }\end{array}$ \\
\hline $\begin{array}{l}\text { FCV } \\
\text { FY }\end{array}$ & $\begin{array}{l}\text { hydrogen fuel cell vehicle } \\
\text { fiscal year }\end{array}$ \\
\hline GHG & greenhouse gas \\
\hline GREET & $\begin{array}{l}\text { Greenhouse gases, Regulated Emissions, and Energy use in Transportation } \\
\text { model }\end{array}$ \\
\hline $\mathrm{HEV}$ & hybrid electric vehicle \\
\hline HFTO & Hydrogen and Fuel Cell Technologies Office \\
\hline HT & heavy truck \\
\hline ISG & integrated starter-generator \\
\hline $\mathrm{LCD}$ & Levelized Cost of Driving \\
\hline LDV & light-duty vehicle \\
\hline $\mathrm{MA}^{3} \mathrm{~T}$ & Market Acceptance of Advanced Automotive Technologies \\
\hline NHTSA & National Highway Traffic Safety Administration \\
\hline $\begin{array}{l}\text { PEV } \\
\text { PHEV }\end{array}$ & $\begin{array}{l}\text { plug-in electric vehicle } \\
\text { plug-in hybrid electric vehicle }\end{array}$ \\
\hline
\end{tabular}


R\&D research and development

SI spark-ignition

SUV sport utility vehicle

VMT vehicle miles traveled

VTO Vehicle Technologies Office

\section{UNITS OF MEASURE}

$\begin{array}{ll}\begin{array}{l}\text { bbl } \\ \text { bpd } \\ \text { Btu }\end{array} & \begin{array}{l}\text { barrel(s) } \\ \text { barrel(s) per day } \\ \text { British thermal unit }\end{array} \\ \text { dge } & \text { diesel gallon equivalent(s) } \\ \text { gal } \\ \text { gge }\end{array} \quad \begin{aligned} & \text { gallon(s) } \\ & \text { gallon gasoline equivalent(s) } \\ & \text { kg } \\ & \text { kWh }\end{aligned} \quad \begin{aligned} & \text { kilogram(s) } \\ & \text { kilowatt-hour(s) } \\ & \text { mi } \\ & \text { MMbpd } \\ & \begin{array}{l}\text { MMt } \\ \text { mpg } \\ \text { mpgde }\end{array}\end{aligned}$




\section{ACKNOWLEDGMENTS}

Technical targets and input for the No Program and Program Success cases came from the expert opinions of technology managers at the U.S. Department of Energy. Gurpreet Singh and Ken Howden gave input regarding the Advanced Combustion Engines and Fuels program. Brian Cunningham, Susan Rogers, and Steven Boyd gave input for the Electrification program. Sarah Kleinbaum and Jerry Gibbs gave input related to the Materials Technology program. Madhur Boloor, American Association for the Advancement of Science, Science \& Technology Policy Fellow in the Vehicle Technologies Office, provided valuable comments.

Vehicles were simulated in Autonomie by Ehsan Islam and Aymeric Rousseau of Argonne National Laboratory. Light-duty vehicle choice modeling support came from Camron Proctor and Steven Wiryadinata of Sandia National Laboratories, and Zhenhong Lin and Fei Xie of Oak Ridge National Laboratory. Dave Gohlke of Argonne provided valuable support in reviewing intermediate results and analysis.

Support and guidance from Vehicle Technologies Office (VTO) analysts Rachael Nealer and Jacob Ward were essential for completing this analysis. 
This page left intentionally blank. 


\section{EXECUTIVE SUMMARY}

Under the U.S. Department of Energy's (DOE's) Office of Energy Efficiency and Renewable Energy, the Vehicle Technologies Office (VTO) invests in research on technologies and innovations, including advanced batteries and electrification; engines and fuels, materials, and energy-efficient mobility systems; hydrogen production, delivery, and storage; and fuel cells. This report documents the estimated benefits of successfully developing and implementing these technologies (the "Program Success" case) relative to a base case (the "No Program" case). The Program Success case represents a future with successful implementation of VTO technologies. The No Program case represents a future in which there is no contribution after Fiscal Year (FY) 2020 by VTO to these technologies. Results presented here are not intended to be predictions. Instead, they represent possible future market outcomes, predicated on assumed technological progress and other future conditions.

Analysis results for the Program Success case indicate that by 2035, the average fuel economy of on-road, light-duty vehicle (LDV) stock could be 19\% higher than in the No Program case. In addition, average fuel economy of the on-road stock of medium- and heavyduty vehicles (referred to as heavy trucks [HTs]) in the same year could be as much as $8 \%$ higher. The resulting petroleum savings in 2035 were estimated to be as high as 1.3 million barrels per day, and reductions in greenhouse gas (GHG) emissions were estimated to be as high as 1,760 million metric tons (MMt) of carbon dioxide equivalent per year, depending on assumptions about the GHG intensity of fuels. Such petroleum reductions result in significant reductions in fuel expenditures for both LDVs and HTs, totaling approximately $\$ 64$ billion annually by 2035 .

Figure ES-1 shows the estimated petroleum consumption in years 2035 and 2050 under both the No Program and Program Success cases, with uncertainty bars showing the range of values calculated (left) and the calculated range of cumulative petroleum savings since 2020 (the cumulative difference in petroleum consumption between the Program Success and No Program cases, right). This report documents a robust range of benefits achieved based on results from two different LDV choice models, the Market Acceptance of Advanced Automotive Technologies ( $\mathrm{MA}^{3} \mathrm{~T}$ ) model, developed by Oak Ridge National Laboratory (Lin and Greene, 2010, 2011; Lin, 2019), and the ParaChoice model, developed by Sandia National Laboratories (Manley et al., 2015; Proctor, 2019), to develop estimates of potential future technology adoption and resulting petroleum use. Figure ES-1 (left) indicates the range of petroleum consumption per day from the two LDV choice models, and the plot on the right shows the range (indicated by the gray band) of potential cumulative petroleum savings after 2020 attributed to all VTO technology programs.

Given VTO technology success, fuel economy would improve by $21 \%$ to $25 \%$ for new LDVs sold in 2035, and by as much as $25 \%$ by 2050 , relative to improvements in the absence of DOE R\&D. Similarly, Program Success for HTs would increase fuel efficiency of new HTs by $18 \%$ by 2035 , and $27 \%$ by 2050 , relative to the No Program case. These increases are shown in Figure ES-2. 

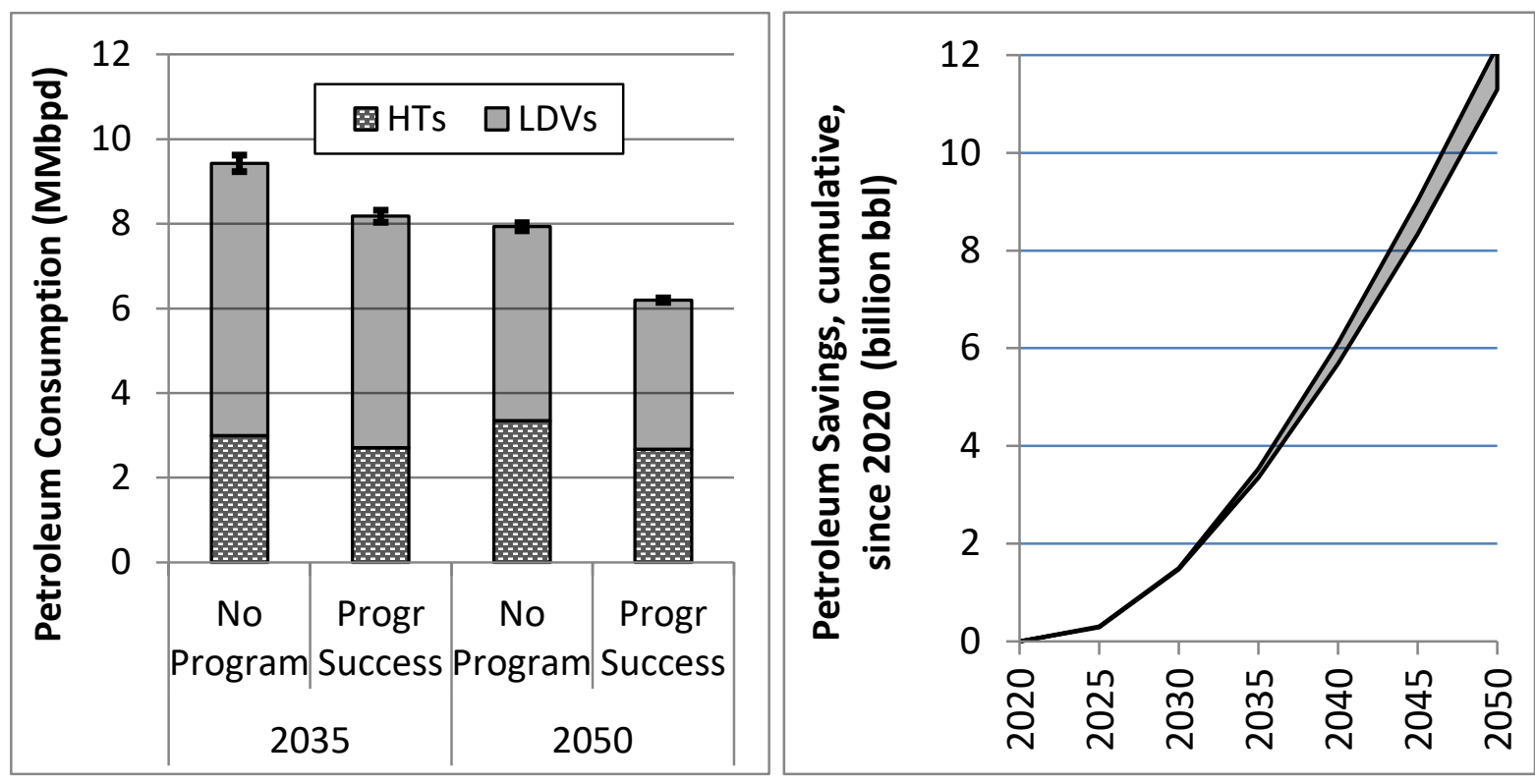

FIGURE ES-1 Estimated On-road Petroleum Consumption under the No Program and Program Success Cases in 2035 and 2050 (left), and Estimated Cumulative Petroleum Savings Attributed to Advancement in VTO- and Hydrogen and Fuel Cell Technologies Office-funded Technologies (right)

LDV-adoption modeling results indicate that advanced-technology vehicles can be less expensive to purchase and use less fuel, resulting in a reduction of consumer cost. In 2035, the potential decreases in annual fuel expenditures for LDVs (the difference between the No Program and Program Success cases) range from $\$ 49$ billion to $\$ 53$ billion (2015 dollars), while expenditures on new LDVs in the same year could be $\$ 27$ billion to $\$ 53$ billion lower in the Program Success case (2015 dollars). In addition, improvements in technology for HTs result in estimated fuel savings in 2035 of $\$ 11$ billion, while vehicle costs increase by $\$ 6$ billion. By 2050 , estimated annual fuel savings for LDVs and HTs reach $\$ 84$ billion to $\$ 87$ billion, while vehicle expenditures are estimated to be $\$ 19$ billion to $\$ 57$ billion lower, as shown in Figure ES-3. Ranges in costs and savings for LDVs represent the results of using two vehicle choice models to estimate the composition of the future vehicle fleet. 

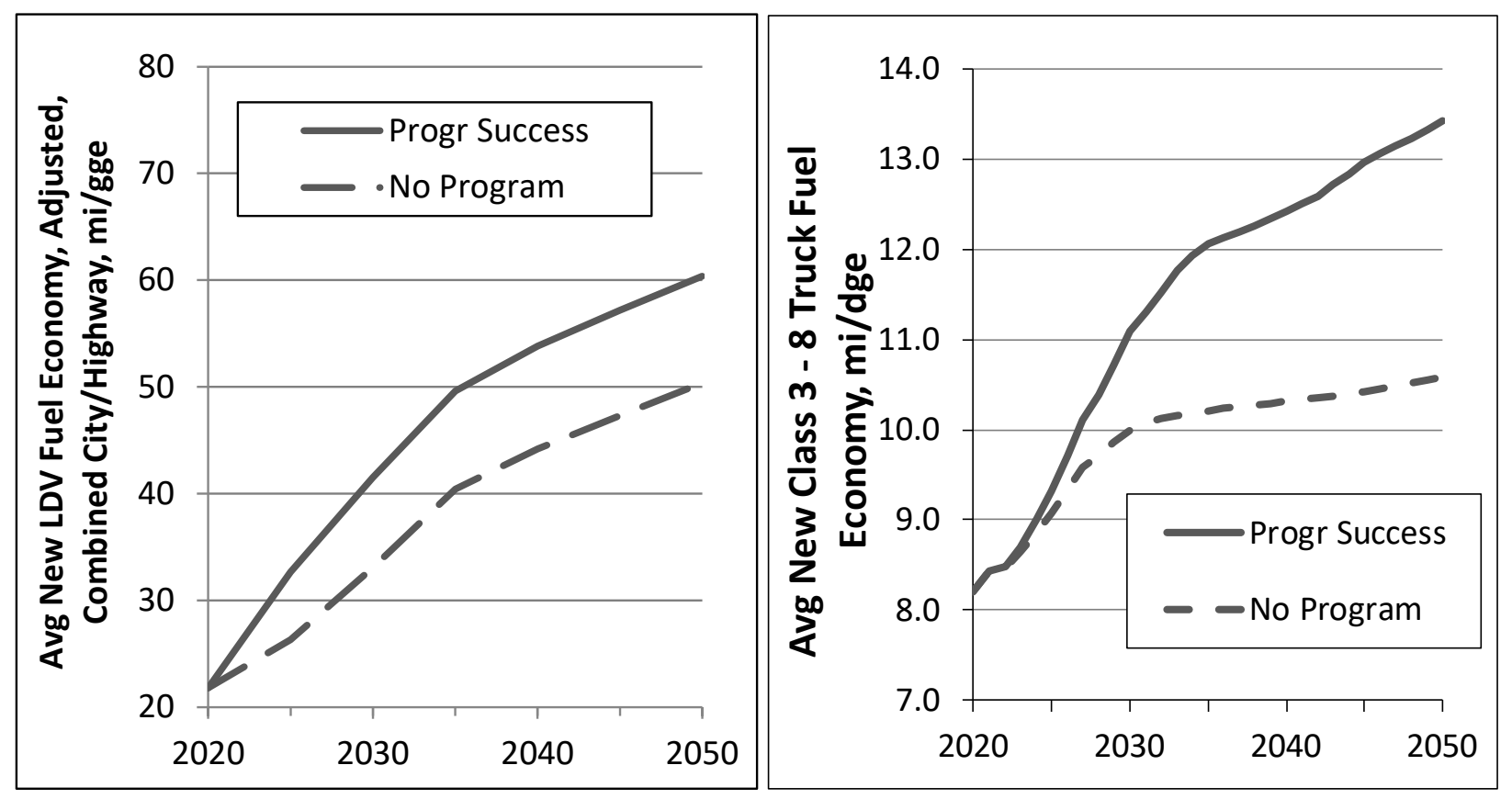

FIGURE ES-2 Fleet-averaged Fuel Efficiency through 2050 for Light-duty Vehicles (left) and Class 3-8 Trucks (right) for the Program Success and No Program Cases

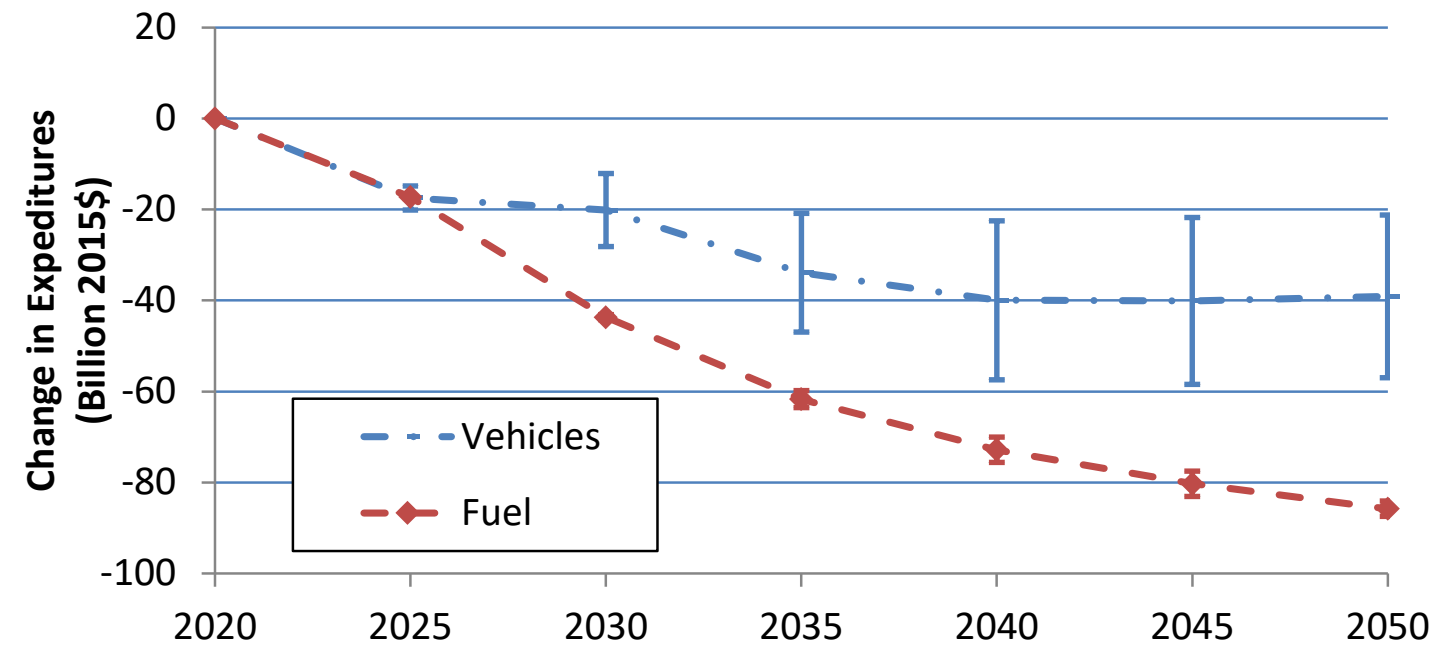

FIGURE ES-3 Difference in Annual National Consumer Costs of Vehicle Purchases and Fuel Costs for On-road Vehicles through 2050 between the No Program and Program Success Cases 
This page left intentionally blank.

ES-4 


\section{INTRODUCTION AND PROGRAM OVERVIEW}

The U.S. Department of Energy's (DOE's) Office of Energy Efficiency and Renewable Energy (EERE) supports early-stage research and development (R\&D) of energy-efficiency and renewable-energy technologies that enhance energy affordability, reliability, and resilience and strengthen U.S. energy security, economic growth, and environmental quality. The Vehicle Technologies Office (VTO) and the Hydrogen and Fuel Cell Technologies Office (HFTO) are two of the offices that constitute EERE's Sustainable Transportation pillar, aiming to provide low-cost, reliable, and efficient energy for transportation of goods and people across America. R\&D areas funded by VTO include batteries, vehicle lightweighting, and advanced combustion. This report quantifies the vehicle-level and national-level benefits of successful VTO R\&D. The analysis in this report concludes that the prospective benefits of these R\&D activities will likely be significant as more fuel-efficient vehicles and no-petroleum vehicles are adopted for use in the U.S.

This report also describes scenarios for the implementation of VTO technologies, as well as methods for estimating the benefits expected from successful adoption of these technologies. Results from the Autonomie advanced vehicle simulation-and-power-flow model quantify future improvements in fuel economy due to the impacts of R\&D activities on traditional and alternative drivetrain technologies (Argonne, undated). Simulations of light-duty vehicles (LDVs) are described in more detail in an accompanying report (Islam et al., 2020). Results of simulations of heavy trucks (HTs) are the same as those used in the most recent prospective program benefits analysis (Stephens et al., 2019). Market-penetration models take these results and other assumptions and estimate how more-efficient vehicles and alternative-fuel vehicles penetrate the new-vehicle market, and finally these market adoption modeling results are used in stock models to estimate the future composition of the on-road stock and to quantify the resulting reductions in energy use and GHG emissions. This analysis links VTO program goals to estimated benefits, as shown in Figure 1-1, which also indicates some of the models used for each step in the process. Methods and assumptions are described in Section 2 and the appendices.

The analyses documented here were done with the assumption that the VTO and HFTO budget levels will remain at recent historical levels. The purpose of this analysis is to assess potential benefits of VTO technologies, recognizing that the technologies supported by HFTO R\&D are likely to improve at the same time. The technology development plans and technology targets for the VTO program are presented in Section 1. Section 2 details the methodology of this benefits analysis. A baseline case, "No Program," against which to measure VTO program benefits, and a "Program Success" case are described for LDVs and HTs. In Section 3, the benefits of the VTO program to the entire U.S. fleet, in terms of reductions in energy use and GHG emissions, and some of the economic implications of these reductions are discussed. Section 4 summarizes key results from the report. References used in support of this document are provided in Section 5. 


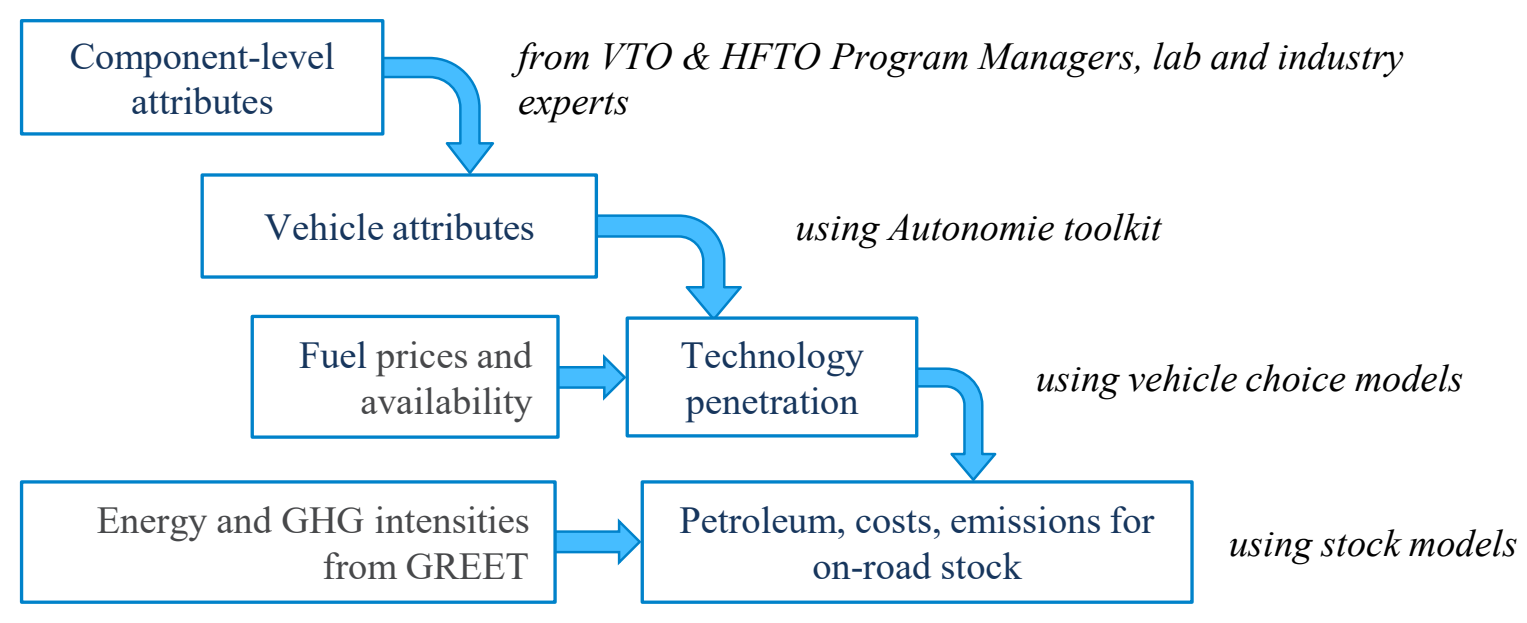

FIGURE 1-1 General Approach and Information Flow in the Benefits Analysis

Deeper technical information is available in the appendices. Appendix A gives details on the LDV analysis, and Appendix B gives details on the HT analysis.

\subsection{OFFICE OF ENERGY EFFICIENCY AND RENEWABLE ENERGY SUSTAINABLE TRANSPORTATION PROGRAMS}

Under the EERE at DOE, the Sustainable Transportation Office comprises the VTO, the HFTO, and the Bioenergy Technologies Office (BETO), as shown in Figure 1-2.

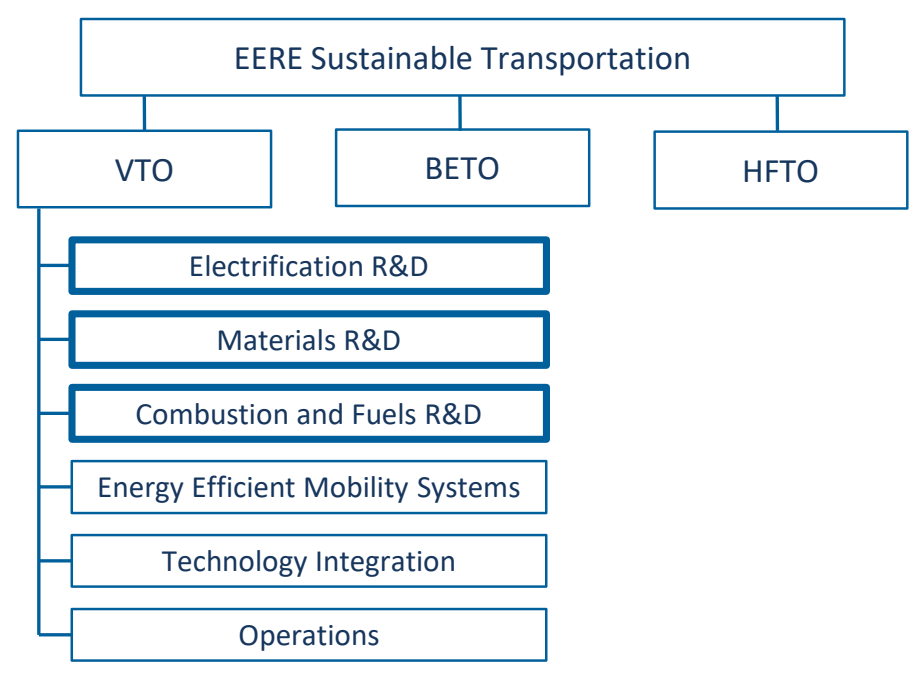

FIGURE 1-2 Organization of Programs in EERE's VTO (R\&D outputs from programs in boxes with bold borders are explored in detail in this report) 
This report focuses on the potential benefits from R\&D supported by VTO; specifically, the technical R\&D programs highlighted in Figure 1-2 and described in Section 1.2.

\subsection{TRANSPORTATION R\&D PROGRAMS}

\subsubsection{Electrification R\&D}

The VTO Electrification R\&D program supports research on the low-cost, high-energy batteries and low-cost, efficient electric drive technologies and charging systems needed to produce efficient plug-in electric vehicles (PEVs) (including all-electric vehicles and plug-in hybrid electric vehicles [PHEVs]). Activities also include R\&D of advanced thermal management technologies and advanced materials for electric drive technologies.

Battery R\&D focuses on the technologies necessary to reduce high-volume battery costs to less than $\$ 100 / \mathrm{kWh}$ and decrease charge time to 15 minutes or less, with an ultimate goal of \$80/kWh (Boyd, 2018; DOE EERE, 2020).

The focus of the Electric Drive, Grid, and Charging R\&D subprogram is on researching technologies and innovations to reduce the cost, significantly increase the power density, and improve the reliability of power electronics, electric motors, and other electric-propulsion components. The electric drive cost target is $\$ 6 / \mathrm{kW}$ for a $100-\mathrm{kW}$ peak power system (Boyd, 2018). R\&D focuses on power electronics and electric motor innovations using advanced, lowcost materials, technologies, and topologies to develop motors, inverters, chargers, and direct current (DC)/DC converters for electric drive vehicles. The subprogram will continue subcomponent R\&D of high-temperature capacitors; high-power, high-density packaging of power semiconductors; and non-rare-earth magnetic materials.

\subsubsection{Advanced Combustion Systems and Fuels R\&D}

The VTO Advanced Combustion Systems and Fuels R\&D program supports research on advanced engine technologies and optimized fuel properties to improve thermal efficiency, reduce exhaust emission, and develop technologies that reduce parasitic losses to decrease petroleum use in U.S. highway transportation.

The Advanced Combustion Engines subprogram supports early-stage R\&D to improve our understanding of and ability to manipulate combustion processes, fuel properties, and catalyst formulations, generating the knowledge and insight necessary for industry to develop the next generation of engines and fuels for LDVs and HTs. As a result, co-optimization of higherefficiency engines and high-performance fuels has the potential to improve LDV fuel economy by 35\% (25\% from advanced-engine research and 10\% from co-optimization with fuels) by 2030 compared to 2015 gasoline vehicles (DOE EERE, 2020). 
The SuperTruck II initiative builds on the earlier VTO SuperTruck initiative and has targets of $55 \%$ or greater engine brake thermal efficiency in real-world operation, improving freight-hauling efficiency by more than $100 \%$ over a 2009 baseline, while staying cost-effective and maintaining comparable performance (Singh, 2018). The knowledge this program generates will increase energy efficiency and improve the fuel economy of passenger and commercial vehicles entering the market. In addition to the SuperTruck II initiative, the $21^{\text {st }}$-Century Truck Partnership (21CTP) is a longstanding government/industry research collaboration between industrial partners across the commercial-truck value chain and government partners with civilian and military missions. The 21CTP Research Blueprint identified reaching a peak engine efficiency of $57 \%$ as a research priority $(21 \mathrm{CTP}, 2019)$. The knowledge generated by this program will increase energy efficiency and improve the fuel economy of passenger and commercial vehicles entering the market.

\subsubsection{Materials Technology $R \& D$}

The VTO Materials Technology program supports vehicle lightweighting and improved propulsion efficiency through the discovery, development, and utilization of materials and enabling technologies for LDVs and HTs. The Materials Technology program seeks to accomplish these technical objectives through research programs with academia, national laboratories, and industry. Weight-reduction R\&D emphasizes the glider, which includes the body, chassis, and interior of the vehicle. A wide range of lightweight materials are considered, such as advanced high-strength steels, aluminum alloys, magnesium alloys, carbon fiber composites, and multi-material systems with performance and manufacturability that greatly exceed today's technologies. VTO research addresses materials and manufacturing challenges spanning processes from extraction to assembly, with an emphasis on establishing tools, capabilities, and material standards for LDVs and HTs.

Propulsion-materials R\&D supports research to develop higher-performance materials that can withstand increasingly extreme environments and address the future properties needs of a variety of relevant high-efficiency powertrain types, sizes, fueling concepts, and combustion modes. The activity will apply advanced characterization and multi-scale computational materials methods, including high-performance computing, to accelerate innovations of cuttingedge structural and after-treatment materials for cleaner, more efficient powertrains. Goals for cost and performance targets are for material technology to enable a $25 \%$ weight reduction for LDVs, including body, chassis, and interior, by 2025 against a 2012 baseline, at a cost of less than $\$ 5$ per pound of weight lost (DOE, 2017). Goals for cost and performance targets are for material technology to enable a weight reduction in HTs of $10 \%$ by 2030 and $20 \%$ by 2050 from a 2010 baseline (VTO, 2013). 


\section{TRANSLATING PROGRAM GOALS INTO MODEL INPUT}

The analysis of advanced technologies to estimate their benefits was based on a threestep, market-based approach. First, the average fuel economy and incremental costs of new vehicles that incorporate DOE-supported technologies were estimated. Second, vehicle choice models were used to estimate the market shares of these platforms in the future. Finally, the modeled fuel economies and market shares were used as inputs to the VISION model (Argonne, 2019a) for LDVs and the HDStock model for HTs, which estimates future on-road vehicle stock and estimates fuel consumption and GHG emissions. From these, the fuel savings and GHG emission reductions were estimated and attributed to VTO technologies. Each of these steps is described below, first for LDVs in Section 2.1, then for HTs in Section 2.2. The overall methodology for benefits analysis is similar to that used previously for the VTO programs, formerly called the Government Performance and Results Act analysis (e.g., Stephens et al., 2017).

For both LDVs and HTs, two cases were developed:

- The No Program case, which assumes that there is no technology improvement or cost reduction beyond 2020 due to the VTO programs; and

- The Program Success case, which assumes that there are future technology improvements and cost reductions that meet VTO program goals.

The economic and environmental benefits were taken to be the differences in the fuel use and GHG emissions between these two cases. The No Program case was developed to represent future vehicle technology, fuel use, and GHG emissions without the effects of technology improvements brought about by the VTO R\&D program. The No Program and Program Success cases for LDVs and HTs are described in the following sections. Results presented here are not intended to be predictions. Instead, they represent possible future market outcomes, predicated on assumed technological progress and other future conditions.

The DOE Energy Information Administration's (EIA's) Annual Energy Outlook (AEO) is the official DOE-wide projection and analysis of future U.S. energy supplies, demands, and prices. Inputs from AEO 2019 were used for fuel prices, vehicle travel, and vehicle ownership in this analysis (EIA, 2019). However, the AEO Reference Case assumes that current policies remain in effect until they sunset. Projections made for the AEO Reference Case thus incorporate assumptions about the market success of technologies historically supported by VTO. A more appropriate baseline case for comparing LDVs and HTs was constructed by estimating the diminishing technological progress over time that would be expected to occur without VTOsupported R\&D. 


\subsection{LDV ANALYSIS}

\subsubsection{LDV Attributes}

For LDVs, parameters describing vehicle component performance, manufacturing costs, and other attributes were estimated for 2015, 2020, 2025, 2030, and 2045 on the basis of input from VTO analysts and program managers and Argonne National Laboratory (Argonne) vehicle technology experts. LDV vehicle simulations are described by Islam et al. (2020). The vehicle technologies and attributes in these years were taken to be representative of technology demonstrated in the laboratory or in prototypes, not in production vehicles offered on the market. It was assumed that five years would be needed to bring these technologies to vehicles on the market. For the No Program case, a baseline based on simulations of future vehicles was developed by assuming that only incremental technology improvements would occur without support from the VTO program. Technology for hydrogen fuel cell vehicles (FCVs) was also assumed to progress more slowly in the No Program case. For the Program Success case, starting assumptions about vehicle component characteristics were based on VTO program targets and relevant vehicle data available in the Autonomie library, a database used with the Autonomie toolkit (Argonne, undated). Attributes of FCVs in the Program Success case were also assumed to advance alongside the VTO-supported technologies. Fuel cells for LDVs were assumed to achieve a peak system efficiency of $68 \%$ by 2050 . Fuel cell and hydrogen storage technology was assumed to progress somewhat more slowly in the No Program case. These starting assumptions were used in the Autonomie toolkit to simulate vehicles in five classes - compact car, midsize car, small sport utility vehicle (SUV), midsize SUV, and pickup truck-with each having the following types of drivetrains using the specified fuel:

- Conventional (Conv) spark-ignition (SI), gasoline;

- Conv compression-ignition (CI), diesel;

- Hybrid electric vehicle (HEV), gasoline;

- Plug-in hybrid electric, SI engines with nominal charge-depleting ranges of 20 and $50 \mathrm{mi}$ (PHEV20, PHEV50), gasoline and electricity;

- Hydrogen FCV; and

- Battery electric vehicle (BEV), with batteries sized for ranges of 200, 300, and $400 \mathrm{mi}$ (BEV200, BEV300, and BEV400), electricity.

For each of these powertrain architectures, the Autonomie model was used to simulate future vehicles, with the powertrain appropriately sized to offer sufficient power, given the weight of the glider (chassis, body, and interior components) and drivability requirements. This was done for each technology scenario to estimate each vehicle's fuel economy on U.S. Environmental Protection Agency (EPA) city and highway driving schedules. The 
incremental costs associated with the advanced powertrains were calculated by using a combination of direct inputs from the VTO for advanced technologies and costs estimated by Ricardo Engineering of Van Buren, Michigan, for near-commercial technologies. Specifically, VTO technology targets were used to estimate costs and performance for the Program Success case for batteries, power electronics and electric motors, and lightweight materials. In addition, costs of fuel cells and on-board hydrogen storage were approximately based on HFTO technology targets for the Program Success case and less optimistic values for the No Program case. Models developed by the Argonne Autonomie group and by Ricardo Engineering were used for estimating costs for other components (Islam et al., 2020).

Vehicle retail price equivalent was estimated by applying a factor of $150 \%$ to the vehicle manufacturing cost, based on reviews of automotive manufacturing indirect costs (Rogozhin et al., 2010; Vyas et al., 2000). Prices were estimated for the base trim level, and all component price models assumed fully learned, high-production-level costs. Further details are documented in a separate report (Islam et al., 2020). This methodology is essentially the same as used in previous benefits analyses, as described by Islam et al. (2017).

The objective of this analysis was not to assess how advanced vehicle technologies might be applied in order to meet future fuel economy or GHG standards, but to assess the influence of technologies independent of the influence of standards. Therefore, automakers' strategic decisions regarding technology adoption were not explicitly modeled; rather, the consumer vehicle choice models were used to represent consumer demand.

Vehicles simulated with these component attributes in years 2015, 2020, 2025, 2030, and 2045 were assumed to be representative of vehicles available in showrooms 5 years later-i.e., in 2020, 2025, 2030, 2035, and 2050, respectively. Attributes of vehicles in showrooms in 2020 were the same for both the No Program and Program Success cases, since the benefits being analyzed were those accruing after 2020. Attributes of vehicles in showrooms in 2025, 2030, 2035, and 2050 in the Program Success case reflected the improved efficiency and lower cost that are expected from completely successful achievement of VTO program goals and commercialization of these technologies.

\subsubsection{LDV Market Penetration and On-road Stock Modeling}

Outputs of the Autonomie modeling were used with fuel prices as inputs to the vehicle choice models in the second step of LDV modeling. Owing to the large uncertainty of future markets for advanced-technology vehicles, two sets of LDV market shares were estimated for the No Program and Program Success cases using two different vehicle choice models under development by VTO:

- Market Acceptance of Advanced Automotive Technologies $\left(\mathrm{MA}^{3} \mathrm{~T}\right)$ model, developed by Oak Ridge National Laboratory (Lin and Greene, 2010, 2011; Lin, 2019) 
- ParaChoice model, developed by Sandia National Laboratories (Manley et al., 2015; Proctor, 2019)

Autonomie simulations provided vehicle attribute inputs to the two vehicle choice models, and assumptions about fuel prices and availability were also supplied, taken from the AEO 2019 Reference Case (EIA, 2019), except for hydrogen. Hydrogen price assumptions were based on HFTO program targets. Fuel prices used in LDV market-penetration modeling are plotted in Figure 2-1. Comparisons of sales and stock shares from the two models are presented in Appendix A. Future energy consumption and GHG emissions by LDVs for both the No Program and Program Success cases were calculated from the sales shares given by the two vehicle choice models using Argonne's VISION model, 2019 version (Argonne, 2019a).

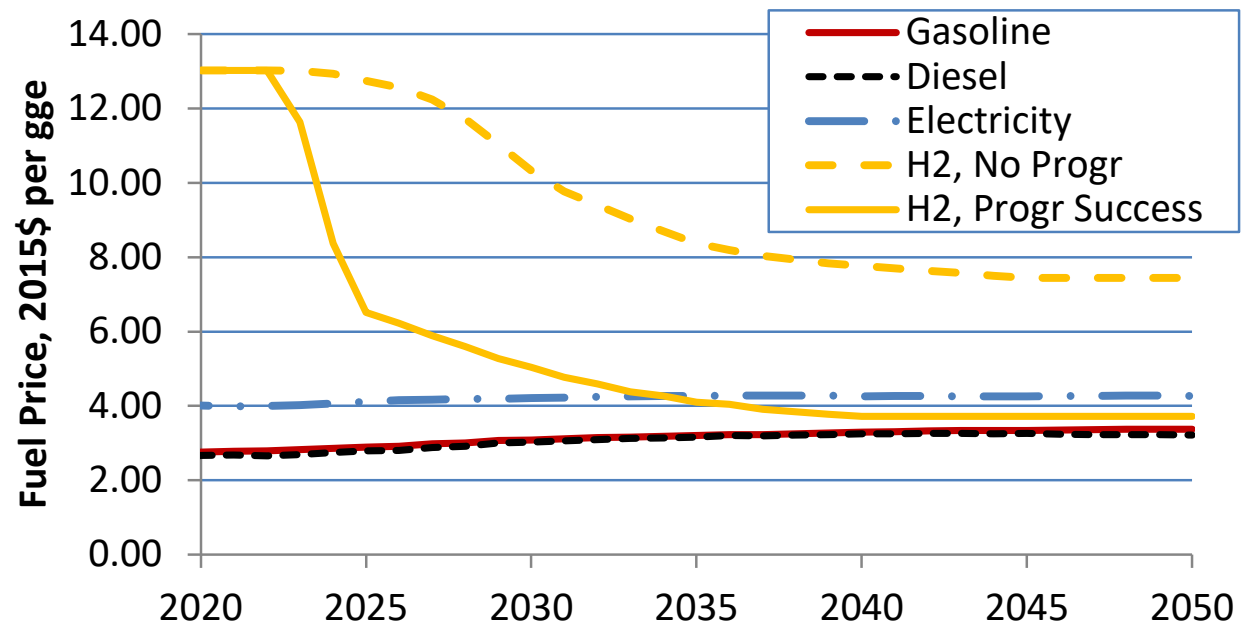

FIGURE 2-1 Fuel Prices Assumed for LDV Analysis

Fuels other than hydrogen were assumed to be fully available. Hydrogen availability was assumed to grow over time, faster in the Program Success case than in the No Program case, as was assumed in previous benefits analyses (Stephens et al., 2017), The assumed availability of hydrogen at public stations relative to the availability of gasoline at public stations is plotted in Figure 2-2. 


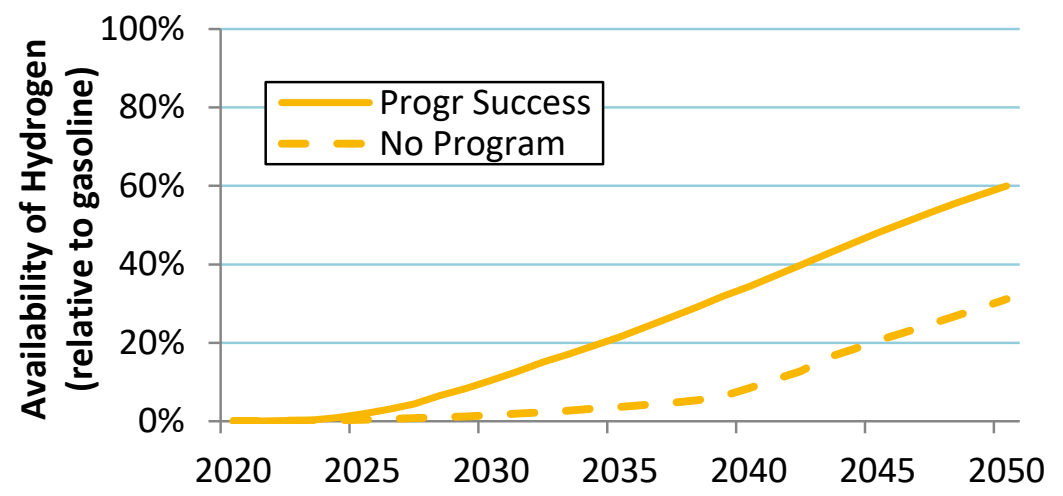

FIGURE 2-2 Availability of Hydrogen Assumed for LDV Analysis

The VISION model is an accounting spreadsheet that calculates output metrics of interest on a national scale. Results from the vehicle choice models with multiple car and light-truck size classes were aggregated to give sales-weighted average values of fuel economy and sales share by technology for cars and light trucks. Fuel-economy values were converted from test-cycle city and highway values to on-road values using EPA-recommended "mileage-based" equations (Bunker 2015). These were harmonically averaged using $43 \%$ city and 57\% highway vehicle miles traveled (VMT) weightings to give combined city/highway on-road fuel economy values. The distances driven by LDVs (VMT per vehicle per year) were based on AEO 2019 (EIA, 2019) but were assumed to be somewhat dependent on the cost per mile, with an elasticity of demand for travel of about -0.1 , the default value in the VISION model (Argonne, 2019a).

Full fuel-cycle GHG emission coefficients for fuels and electricity from the Argonne GREET (Greenhouse gases, Regulated Emissions, and Energy use in Transportation) model (2018 version) were used to estimate GHG emissions (Argonne, 2019b), using two different assumed electricity generation mixes and hydrogen pathways in the VISION model. Two projections of electricity grid mixes and hydrogen pathways were assumed for both the No Program and Program Success cases to give ranges of primary energy and GHG emissions for both cases. One assumes an electric grid similar to that in the AEO 2019 Reference case (EIA, 2019) and hydrogen production resembling the current production mix (one-third from renewable power and two-thirds from methane reforming); the other, a high-renewables electricity and hydrogen pathway mix, assumes $80 \%$ of electricity is produced by renewables by 2050 , and $80 \%$ of hydrogen is produced by electrolysis using renewable electricity by 2050 . The assumptions for the high-renewables case were loosely based on scenarios in the Renewable Energy Futures study (NREL, 2012). The electric grid mixes and the GHG intensities of electricity for these scenarios are given in Table 2-1. The fractions of hydrogen produced by SMR and by electrolysis using renewable (wind and solar) power and the GHG intensities of the hydrogen produced by these two mixes are given in Table 2-2. 
TABLE 2-1 GHG Intensities of Electricity in the Default and High-renewables Electricity and Hydrogen Pathways

\begin{tabular}{lrrrr}
\hline \multicolumn{1}{c}{ Electricity Generation Mix } & 2020 & 2030 & 2040 & 2050 \\
\hline Default Grid Mix & & & & \\
Coal (\%) & 24.9 & 22.3 & 19.2 & 17.3 \\
Petroleum (\%) & 0.4 & 0.2 & 0.2 & 0.1 \\
Natural Gas (\%) & 36.5 & 38.6 & 39.6 & 39.0 \\
Nuclear (\%) & 18.6 & 14.6 & 13.5 & 12.4 \\
Renewables (\%) & 19.7 & 24.2 & 27.6 & 31.2 \\
GHG intensity, well-to-tank & 92.9 & 89.0 & 83.0 & 78.2 \\
$\quad$ (MMt CO -eq/quad electricity) $_{\text {High-renewables Grid Mix }}$ & & & & \\
Coal (\%) & 24.9 & 16.6 & 8.3 & 0.0 \\
Petroleum (\%) & 0.4 & 0.3 & 0.1 & 0.0 \\
Natural Gas (\%) & 36.5 & 26.0 & 15.5 & 5.0 \\
Nuclear (\%) & 18.6 & 17.4 & 16.2 & 15.0 \\
Renewables (\%) & 19.7 & 39.8 & 59.9 & 80.0 \\
GHG intensity, well-to-tank & 92.9 & 64.0 & 35.1 & 6.1 \\
$\quad$ (MMt CO 2 -eq/quad electricity) & & & & \\
\hline
\end{tabular}

TABLE 2-2 GHG Intensities of Hydrogen $\left(\mathrm{H}_{2}\right)$ in the Default and High-renewables Electricity and Hydrogen Pathway Mixes

\begin{tabular}{|c|c|c|c|c|}
\hline Hydrogen Pathway Mix & 2020 & 2030 & 2040 & 2050 \\
\hline \multicolumn{5}{|l|}{ Default $\mathrm{H}_{2}$ pathways } \\
\hline Natural gas reforming at station (\%) & 0 & 0 & 0 & 0 \\
\hline Natural gas reforming, central (\%) & 67 & 67 & 67 & 67 \\
\hline Electrolysis, renewable power $(\%)$ & 33 & 33 & 33 & 33 \\
\hline $\begin{array}{l}\text { GHG intensity, well-to-tank } \\
\left.\text { (MMt } \mathrm{CO}_{2} \text {-eq/quad } \mathrm{H}_{2}\right)\end{array}$ & 51.9 & 51.8 & 51.3 & 51.1 \\
\hline \multicolumn{5}{|l|}{ High-renewables $\mathrm{H}_{2}$ pathways } \\
\hline Natural gas reforming at station (\%) & 67 & 50 & 20 & 0 \\
\hline Natural gas reforming, central (\%) & 0 & 10 & 20 & 20 \\
\hline Electrolysis, renewable power (\%) & 33 & 40 & 60 & 80 \\
\hline $\begin{array}{l}\text { GHG intensity, well-to-tank } \\
\left(\mathrm{MMt} \mathrm{CO}_{2} \text {-eq/quad } \mathrm{H}_{2}\right)\end{array}$ & 51.9 & 47.5 & 34.9 & 22.5 \\
\hline
\end{tabular}

\subsection{HEAVY-TRUCK ANALYSIS}

As with LDVs, the analysis of HT benefits from VTO technologies was a four-step process, in which (1) a baseline (No Program) case was developed, (2) fuel economy values and incremental costs of new vehicles with DOE-supported technologies were estimated, (3) market penetration of advanced-technology vehicles was modeled for Program Success vs. No Program cases, and (4) the resulting fuel savings and GHG reductions were calculated as the differences 
between the two cases. Sections 2.2.1 through 2.2.3 describe each step of the benefits analysis for HTs.

Two linked models were used to estimate VTO-technology benefits for HTs. The TRUCK model calculates annual fuel savings for advanced-technology vehicles relative to baseline vehicles and uses a payback algorithm to model market penetrations within 20,000-mile mileage cohorts. The model estimates annual mileage-weighted new-fleet fuel economies by powertrain, share of miles that are centrally and non-centrally refueled, and share of miles that are traveled on separate fuels for bi-fuel vehicles (e.g., PHEVs). It is linked to a separate stock accounting model (HDStock) that is used to estimate future miles of travel and fuel use by in-use vehicles and to estimate energy and fuel savings, relative to the baseline, attributable to each technology platform. This tool uses methodology and parameters, i.e. sales, scrappage rates, and age-dependent mileage, consistent with the EIA's National Energy Modeling System and with EPA and National Highway Traffic Safety Administration (NHTSA) fuel consumption regulatory classifications (EPA and NHTSA, 2016). HDStock is calibrated to produce consumption results within about $\pm 1.2 \%$ of the AEO 2019 Reference Case (EIA, 2019).

\subsubsection{Heavy-truck Baseline}

The baseline was developed from the AEO 2019 Reference Case. New-heavy-vehiclefleet fuel economies from the AEO Reference Case were adjusted to remove the impact of projected penetrations of advanced technologies supported by ongoing and proposed future DOE funding. This adjusted new-fleet fuel economy was used as input to HDStock to calculate baseline in-use fleet fuel consumption.

The fuel economy projection from the AEO 2019 Reference Case was evaluated to assess the impact of market penetration of new technologies supported by DOE funding. EIA provided individual component technology contributions to truck fuel economy and market penetration of these technologies in the AEO 2019 Reference Case. The technology penetrations are calculated at a lower level of disaggregation (19 sub-classes) than the AEO output tables ( 3 broad categories). Therefore, the penetrations were analyzed in subclasses consistent with the EPA/NHTSA fuel consumption rules and HDStock model segmentation as shown below:

- Heavy-duty Trucks (weight classes 7\&8)

- Class 7\&8 Tractor Sleeper Cabs

- Class 7\&8 Tractor Day Cabs

- Class 7\&8 Vocational Trucks

- Medium-duty Trucks (weight classes 4-6)

"Vocational" as used in the above list was adopted from EPA/NHTSA and refers to all trucks that are not tractors, conventional vans, or pickups. These include van- or box-type trucks as well as vehicles such as cement mixers, refuse haulers, dump trucks, and utility vehicles, which are more commonly referred to as vocational (or work) trucks. 
Consistent with prior analyses of benefits due to VTO programs (e.g., Stephens et al., 2019; Stephens et al., 2016), this analysis considers only technologies developed for diesel trucks in weight classes 4-8. As a result, the sales distribution and fuel economy of Class 4-8 gasoline trucks and all Class 3 trucks in the Program Success case remain the same as in the No Program case. Further, no benefits are claimed for the market penetration of natural gas and propane trucks found in the AEO 2019 Reference Case, and the Program Success case does not estimate additional penetration of these vehicles as a result of VTO funding. Current VTO heavy-vehicle research initiatives do not specifically address propane or gasoline HTs or the pickups and vans that constitute the majority of Class 3 diesel trucks.

While VTO-funded research for both LDVs and HTs is likely to have spillovers that improve the fuel economy of the omitted gasoline and diesel vehicles, this impact is estimated to be relatively small compared to the fuel savings for Class $4-8$ diesel trucks. This assumption is based on the fact that Class 4-8 diesel trucks consume much more fuel than the vehicles that were not considered. The AEO 2019 Reference Case projects that the trucks covered by this analysis (Class 4-8 diesel) will be responsible for nearly $88 \%$ of Class 3-8 fuel consumption in 2030, after the Phase 2 Rule is fully implemented (EIA, 2019). In addition, medium-duty trucks in general, and gasoline trucks especially, are driven fewer miles annually and have a higher baseline fuel economy compared to larger, diesel trucks. Therefore, fuel cost savings accrue fairly slowly, extending the payback period for investment in advanced technologies and resulting in lower market adoption rates and lower fleet fuel savings. Technologies funded by HFTO were included in this analysis and reflect current technical targets for FCV components and fuel infrastructure.

\subsubsection{Heavy-truck Advanced Technology Modeling}

Argonne's Autonomie team analyzed HT "Low" and "High" technology progress scenarios, with the High case representing the Program Success case consistent with VTO research areas and goals (Islam et al., 2020). The Autonomie "Low" case is intended to represent a "business as usual" technology development trajectory and was not simulated specifically to match the AEO Reference Case vehicles without VTO funding. The Autonomie "High" case represents achievement of VTO program goals. As with LDV simulations, fuel cell and hydrogen storage technologies were assumed to improve at a rate approximating the HFTO R\&D goals in the Program Success case. Simulated powertrains included conventional diesel, diesel with integrated starter-generator (ISG), diesel HEV, diesel PHEV, BEV, and FCV. All powertrains were modeled for a range of medium- and heavy-vehicle classes and types, including vehicles within the TRUCK market segments as described in Section 2.2.3. Details on vehicle simulations are provided by Vijayagopal et al. (2019).

\subsubsection{Heavy-truck Market-penetration and Stock Modeling}

In the second phase of the HT analysis, the fuel economy improvements and estimated costs from Autonomie simulations were used to develop inputs for the TRUCK marketpenetration model to estimate market penetration of the advanced platforms for 2020 through 
2050. All powertrains were modeled for a range of medium- and heavy-vehicle classes and types, including vehicles within the TRUCK market segments shown in Table 2-3. The TRUCK model compares alternative vehicle choices to a baseline (fleet average) vehicle (designated $\mathrm{x}$ ) and can accommodate up to five alternatives (designated A through E). The choice "Base" represents the baseline or No Program technology as described in Section 2.2.1. A blank in Table 2-3 indicates that a powertrain was not a choice in a given market segment.

TABLE 2-3 Powertrains Used in each Vehicle Class/Type Market in the TRUCK Model

\begin{tabular}{lccccccc}
\hline \multicolumn{1}{c}{ Class/Segment } & Base & $\begin{array}{c}\text { Advanced } \\
\text { Conv }\end{array}$ & ISG & HEV & PHEV & BEV & FCV \\
\hline Class 7\&8 Sleeper Cab & $\mathrm{x}$ & $\mathrm{A}$ & $\mathrm{B}$ & $\mathrm{C}$ & $\mathrm{D}$ & & $\mathrm{E}$ \\
Class 7\&8 Day Cab & $\mathrm{x}$ & $\mathrm{A}$ & $\mathrm{B}$ & & $\mathrm{C}$ & $\mathrm{D}$ & $\mathrm{E}$ \\
Class 7\&8 Voc & $\mathrm{x}$ & $\mathrm{A}$ & $\mathrm{B}$ & $\mathrm{C}$ & $\mathrm{D}$ & $\mathrm{E}$ & \\
Class 4-6 Voc & $\mathrm{x}$ & $\mathrm{A}$ & & $\mathrm{B}$ & $\mathrm{C}$ & $\mathrm{D}$ & $\mathrm{E}$ \\
\hline
\end{tabular}

Note: A, B, C, D, and E represent technology slots in the TRUCK market-penetration model. A blank indicates that the technology was not included in the specified market class.

Autonomie simulation results - specifically, fuel economy (miles per gallon), cost, and charge-depletion range (for plug-in vehicles) - for vehicles in Classes 4, 6, and 8 were used to represent each of the markets in the analysis. Autonomie simulations have been described by Stephens et al. (2019) and Vijayagopal et al. (2019), and spreadsheets with simulation inputs and results are available as attachments to those reports. Class 4 and 6 delivery trucks were assumed to be representative of the medium-duty truck fleet; when developing weighting factors to combine Class 4 and Class 6 attributes in a single representative vehicle, Class 5 market share was split evenly between Classes 4 and 6. Three Class 8 sleeper-cab tractors, three Class 8 daycab tractors, and one vocational heavy-duty truck were used to represent Class $7 \& 8$ trucks.

Autonomie outputs for three regulatory drive cycles were combined using weighting factors from EPA/NHTSA to establish fuel economies comparable to the sales fleet values from the AEO. Since the baseline vehicle for this round of benefits analysis was developed separately on the basis of the AEO 2019 Reference Case (EIA, 2019) and represents a sales fleet average vehicle, multipliers were derived from the Autonomie data to generate fuel economy values for the alternative powertrains. This approach ensures that the alternative powertrain fuel economy improvements over the derived baseline vehicle are proportional to Autonomie alternative powertrain fuel economy improvements over the Autonomie Conventional Low vehicle. However, because the baseline fuel economy generally remains flat after 2030, the 2030 Conventional Low vehicle is used as the reference through 2050.

Current vehicle prices were estimated using vehicle price information extracted from Truck Paper (2019) and Commercial Truck Trader (2019) for each of the vehicle types, and prices were aggregated to the size classes modeled as was done in the previous benefits analysis 
(Stephens et al., 2019). The results were used as baseline vehicle prices through 2020. The annual percent change in Autonomie's estimated price for Conventional Low was applied to the current prices for 2021 through 2030, then held constant through 2050. Incremental costs for the alternative powertrains (Autonomie-estimated price difference from the Conventional Low reference) were applied directly to this baseline price.

Fuel prices for all but hydrogen fuels were taken from the AEO 2019 Reference Case (EIA, 2019). Prices for hydrogen for non-centrally refueled fleets were based on HFTO targets for light-duty FCVs. Assumed future fuel prices are intended to reflect the price paid at the pump, including hydrogen production, distribution, and dispensing. Slightly lower hydrogen prices were assumed for centrally refueled fleets, which are expected to have a higher utilization of refueling equipment and correspondingly lower capital costs. Diesel prices for centrally refueled fleets were assumed to be slightly lower than non-central prices, in accordance with the Clean Cities 2018 Alternative Fuel Price Report (DOE, 2018). Prices assumed for electricity and diesel, in 2015 dollars per diesel gallon equivalent (dge), and hydrogen prices in 2015 dollars per kilogram are shown in Figure 2-3.

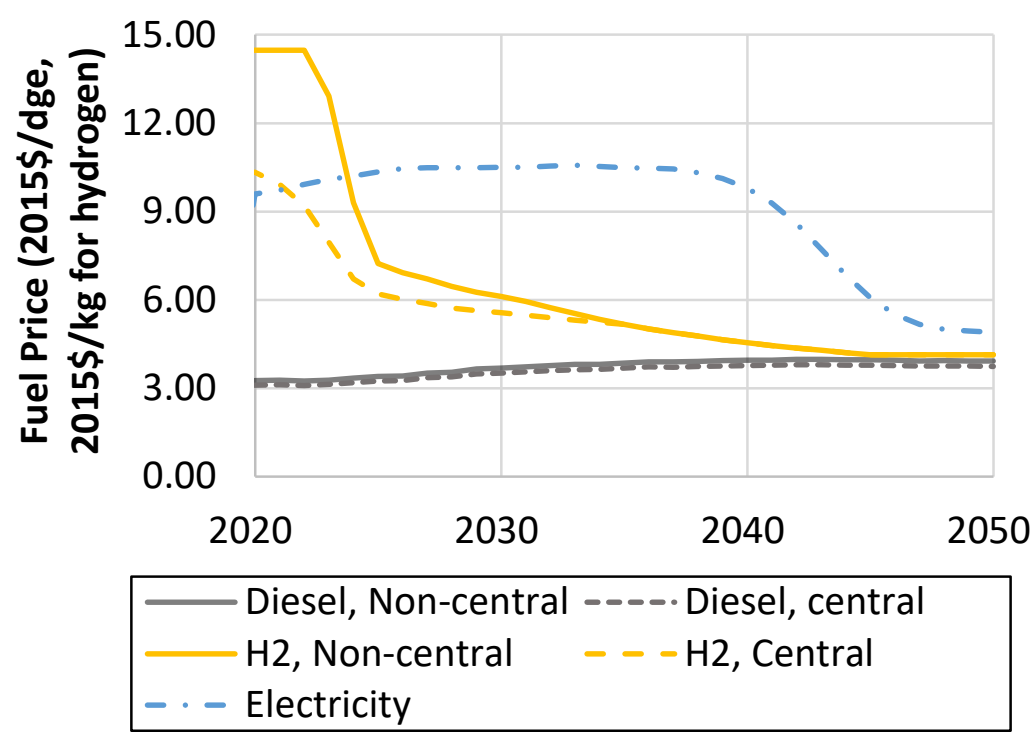

FIGURE 2-3 Fuel Prices Assumed for Diesel and Electricity in the HT Analysis

The TRUCK model models market acceptance by comparing incremental costs and the value of fuel savings with buyer preferences for different payback periods. Since fuel-efficient technology is more cost-effective for trucks with higher annual mileage, the payback algorithm is applied to multiple mileage cohorts rather than assuming the fleet-averaged mileage for all trucks. TRUCK then reports market share as a fraction of total miles driven by trucks of a particular model year in the first year of ownership. Finally, for BEVs, the TRUCK model checks whether or not a given truck has sufficient range to meet daily driving requirements. In 
cases where the BEV does not have enough range to achieve the daily range required in a single charge (depending on the mileage cohort), the BEV is not offered to the market. For PHEVs, the all-electric range is compared to the daily range requirement and used to derive the utility factor (\% of miles on electricity) and net diesel and electricity consumption per mile. This methodology assumes drivers will maximize operation on electricity and have sufficient time and access to fully charge off-shift, but do not employ opportunity charging en route.

The TRUCK market-penetration model also takes into account availability of fuels (other than gasoline and diesel). Fuels other than electricity and hydrogen were assumed to be fully available at public fuel stations and to centrally refueled fleets. Electricity and hydrogen were assumed to be fully available to centrally refueled fleets; for non-centrally refueled fleets, they were assumed to be available at a fraction of public stations. This fraction was assumed to increase over time. For electric charging stations, this fraction was based on extrapolations of historical numbers of gasoline and public charging stations from the Alternative Fuels Data Center (DOE, 2019). Historical station numbers for LDV stations were used, owing to lack of data or projections for charging stations for electric HTs. For hydrogen, the fraction was based on scenarios used in the LDV benefits analysis described in Section 2.1.2.

The future availability of hydrogen and electricity at public stations (those used by noncentrally refueled fleets) is highly uncertain. To assess the effect of the resulting uncertainty on market penetration, we ran a side case assuming full availability of all fuels, with other assumptions the same as in the Program Success scenario. Market-penetration results for the side case are described in Appendix B. The analysis of the side case was limited to market penetration; no stock-level results were developed, owing to constraints of modeling and resource limitations.

Ranges of future GHG intensities for electricity and hydrogen were assumed, consistent with what was assumed in the LDV analysis, described in Section 2.1.2.

For the third and final step of the HT benefits analysis, fuel use by HTs in the Program Success case was compared with that in the baseline No Program case. Since the VISION model currently is not configured to analyze all the heavy-vehicle platforms modeled for the HT analysis, information from the latest AEO (EIA, 2019) and the associated model input files, including total truck sales, age-specific average annual mileage, and scrappage rates, were applied in an additional spreadsheet tool, HDStock, which tracks the stock of heavy vehicles. Fuel use by these trucks was calculated first by assuming the simulated fuel economies and TRUCK market penetrations, and then by assuming the baseline No Program fuel economy for all trucks. The difference between these two calculations provides an estimate of potential energy and GHG emission savings attributable to the VTO program. The modeled market penetration by advanced-technology HTs and the resulting average fuel economy are discussed in Appendix B. 


\section{OVERALL BENEFITS OF VTO R\&D}

Reductions in energy use and GHG emissions attributable to VTO program technologies were estimated for the entire U.S. fleet (LDVs and HTs) as described in this report. Table 3-1 quantifies the cumulative energy and emissions savings estimated to occur after 2020, energy and emissions reduction rates in each year, and the economic implications through 2050. Ranges in Table 3-1 represent national-scale impacts from each fleet as derived from each LDV choice model. Ranges for GHG emissions also reflect the range of GHG intensities assumed for electricity and hydrogen.

Reductions in petroleum consumption and GHG emissions in LDVs were estimated using two different LDV choice models, while only one set of results was developed for HTs. Two sets of assumptions were made about the GHG intensities of electricity and hydrogen. Values for LDVs are therefore shown as ranges, which show considerable uncertainty because of the wide range of market-penetration results for advanced-technology LDVs under both the No Program and Program Success cases. Since the modeled market penetration of advanced-technology vehicles differed between the two LDV choice models, the petroleum use results were also different. Ranges shown for GHG emissions reflect both the ranges of LDV market penetration and differences in GHG intensities assumed for both LDVs and HTs.

Section 3.1 describes the petroleum consumption benefits realized as a result of VTO technologies. Section 3.2 examines the economic benefits to the end-consumer resulting from reduced petroleum consumption. Section 3.3 looks at environmental benefits due to VTO technologies. Together, these benefits demonstrate that a successful VTO program will significantly reduce oil consumption, consumer energy expenditures, and GHG emissions. Moreover, these programs offer American drivers benefits not captured in Table 3-1, including increased mobility, reduced pollution, and reduced exposure to potential oil price shocks. Thus, continuing to invest government resources in advanced vehicle technologies would have significant economic value in the U.S. transportation sector; help consumers and businesses save money; and increase the use of secure domestic energy sources.

As shown in Table 3-1, the Program Success case reduces total fuel use relative to the No Program case. Petroleum consumption is greatly reduced, in particular, for LDVs, as shown in Figure 3-1. Because of the growth in electric vehicles and FCVs over the time span examined, hydrogen and electricity use each increase, relative to today, in both the No Program and Program Success cases. Electricity and hydrogen use are both higher in the Program Success case than in the No Program case because of the increase in PEVs and FCVs, despite the higher energy efficiency of these vehicles in the Program Success case. However, the increases in electricity and hydrogen use are far smaller than the decrease in petroleum use. 
TABLE 3-1 Estimated Benefits of VTO R\&D

\begin{tabular}{|c|c|c|c|c|}
\hline \multirow[b]{2}{*}{ Metric } & \multicolumn{4}{|c|}{ Year } \\
\hline & 2025 & 2030 & 2035 & 2050 \\
\hline \multicolumn{5}{|l|}{ Oil savings, cumulative (billion bbl) ${ }^{\mathrm{a}}$} \\
\hline LDVs & 0.3 & $1.3-1.4$ & $2.9-3.1$ & $8.3-9.2$ \\
\hline HTs & 0.01 & 0.1 & 0.5 & 3.0 \\
\hline Total & 0.3 & 1.5 & $3.3-3.5$ & $11.3-12.2$ \\
\hline \multicolumn{5}{|l|}{ Oil savings rate (million bpd) ${ }^{\mathrm{a}}$} \\
\hline LDVs & 0.3 & $0.7-0.8$ & $0.9-1.0$ & $1.0-1.1$ \\
\hline HTs & 0.02 & 0.1 & 0.3 & 0.7 \\
\hline Total & $0.3-0.4$ & $0.8-0.9$ & $1.1-1.3$ & $1.7-1.8$ \\
\hline $\begin{array}{l}\text { Primary energy savings, cumulative } \\
\text { (quads) }^{\mathrm{a}}\end{array}$ & 2 & 10 & $23-24$ & $72-83$ \\
\hline Primary energy savings, annual (quads/yr) & 0.9 & $2.1-2.2$ & $2.8-3.1$ & $3.5-4.2$ \\
\hline \multicolumn{5}{|l|}{ New-vehicle mpg improvement (percent) ${ }^{b}$} \\
\hline LDVs & $22-26 \%$ & $25-26 \%$ & $21-25 \%$ & $14-25 \%$ \\
\hline HTs & $3 \%$ & $11 \%$ & $18 \%$ & $27 \%$ \\
\hline \multicolumn{5}{|l|}{$\begin{array}{l}\text { On-road-stock mpg improvement } \\
\text { (percent) }{ }^{\mathrm{b}}\end{array}$} \\
\hline LDVs & $5 \%$ & $12 \%$ & $18-19 \%$ & $25 \%$ \\
\hline HTs & $3 \%$ & $4 \%$ & $8 \%$ & $20 \%$ \\
\hline \multicolumn{5}{|l|}{$\begin{array}{l}\text { Reduction in annual fuel expenditures } \\
\text { (billion } 2015 \$ / y r)^{\mathrm{a}}\end{array}$} \\
\hline LDVs & $-17--16$ & $-39--38$ & $-53--49$ & $-61--57$ \\
\hline HTs & -1 & -5 & -11 & -27 \\
\hline Total & $-18-17$ & $-44--43$ & $-64--60$ & $-87--84$ \\
\hline \multicolumn{5}{|l|}{$\begin{array}{l}\text { Increase in annual expenditures for new- } \\
\text { vehicle purchases (billion } 2015 \$ / \mathrm{yr})^{\mathrm{a}}\end{array}$} \\
\hline LDVs & $-22--17$ & $-33--17$ & $-53--27$ & $-64--28$ \\
\hline HTs & 2 & 5 & 6 & 7 \\
\hline Total & $-20--15$ & $-28--12$ & $-47--21$ & $-57--21$ \\
\hline $\begin{array}{l}\text { GHG emissions reduction, cumulative } \\
\text { (million tons } \mathrm{CO}_{2} \text {-eq) } \text { ) }^{\mathrm{a}}\end{array}$ & $140-150$ & $730-750$ & $1,640-1,770$ & $5,260-6,570$ \\
\hline \multicolumn{5}{|l|}{ 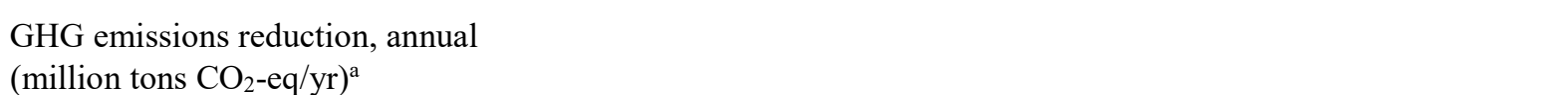 } \\
\hline LDVs & $58-60$ & $130-139$ & $163-193$ & $175-278$ \\
\hline HTs & 3 & 19 & $38-39$ & $92-110$ \\
\hline Total & $62-64$ & $148-157$ & $200-232$ & $267-388$ \\
\hline \multicolumn{5}{|c|}{$\begin{array}{l}\text { a "Reductions" and "savings" were calculated as the difference between the results from the Program Success case (i.e., in } \\
\text { which requested DOE funding for this technology is received and the program is successful) and the results from the } \\
\text { baseline (No Program) case (i.e., in which there is no future DOE funding for this technology). Negative reduction values } \\
\text { reflect increases. All cumulative metrics are based on results beginning in } 2020 \text {. }\end{array}$} \\
\hline
\end{tabular}



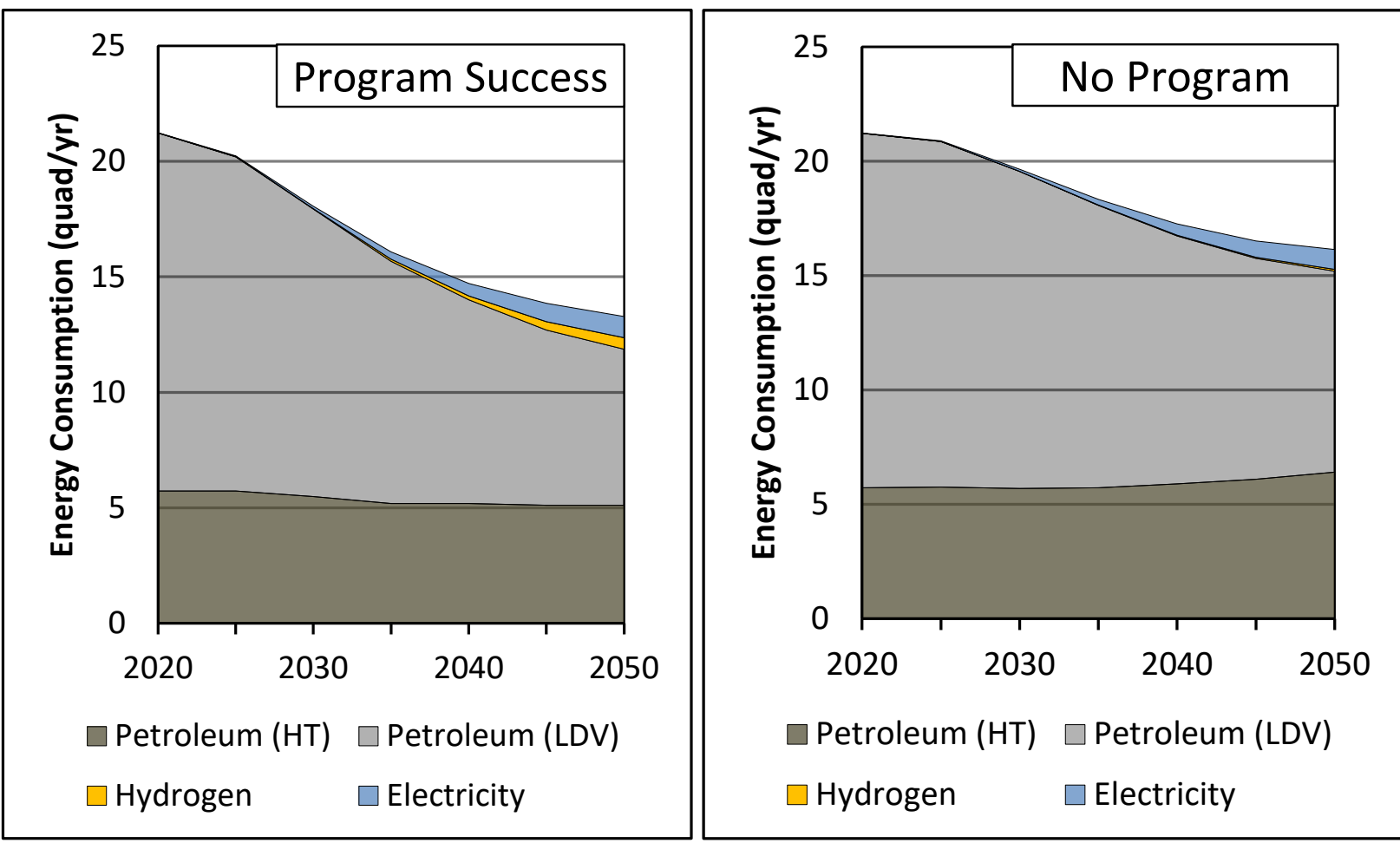

FIGURE 3-1 On-road Fuel Consumption by Fuel Type through 2050 for the Program Success and No Program Cases

\subsection{PETROLEUM BENEFITS}

The potential reductions in petroleum use from successful VTO programs are significant: up to 1.3 million barrels per day (MMbpd) in 2035 and 1.8 MMbpd in 2050. The petroleum savings estimated for 2035 amount to as much as 10\% of the total U.S. petroleum consumption in the same year as estimated in the AEO 2019 Reference Case (EIA 2019). The U.S. transportation sector is petroleum-intensive, with $91 \%$ of the energy used by the sector coming from petroleum in 2019. In 2018 (the most recent year for which this value was reported [Davis and Boundy, 2020]), transportation-sector petroleum consumption represented $69 \%$ of total U.S. petroleum consumption.

Figure 3-2 shows the total petroleum savings attributable to the VTO program in 2035 and 2050 and the total cumulative petroleum savings since 2019. Gains are slow until 2025, but increase rapidly after 2025 because of the time it takes for technology to reach the market. VTO funds research across a broad spectrum of commercialization, but much of the R\&D is at early stages, with technology readiness levels between 2 and 5 . 

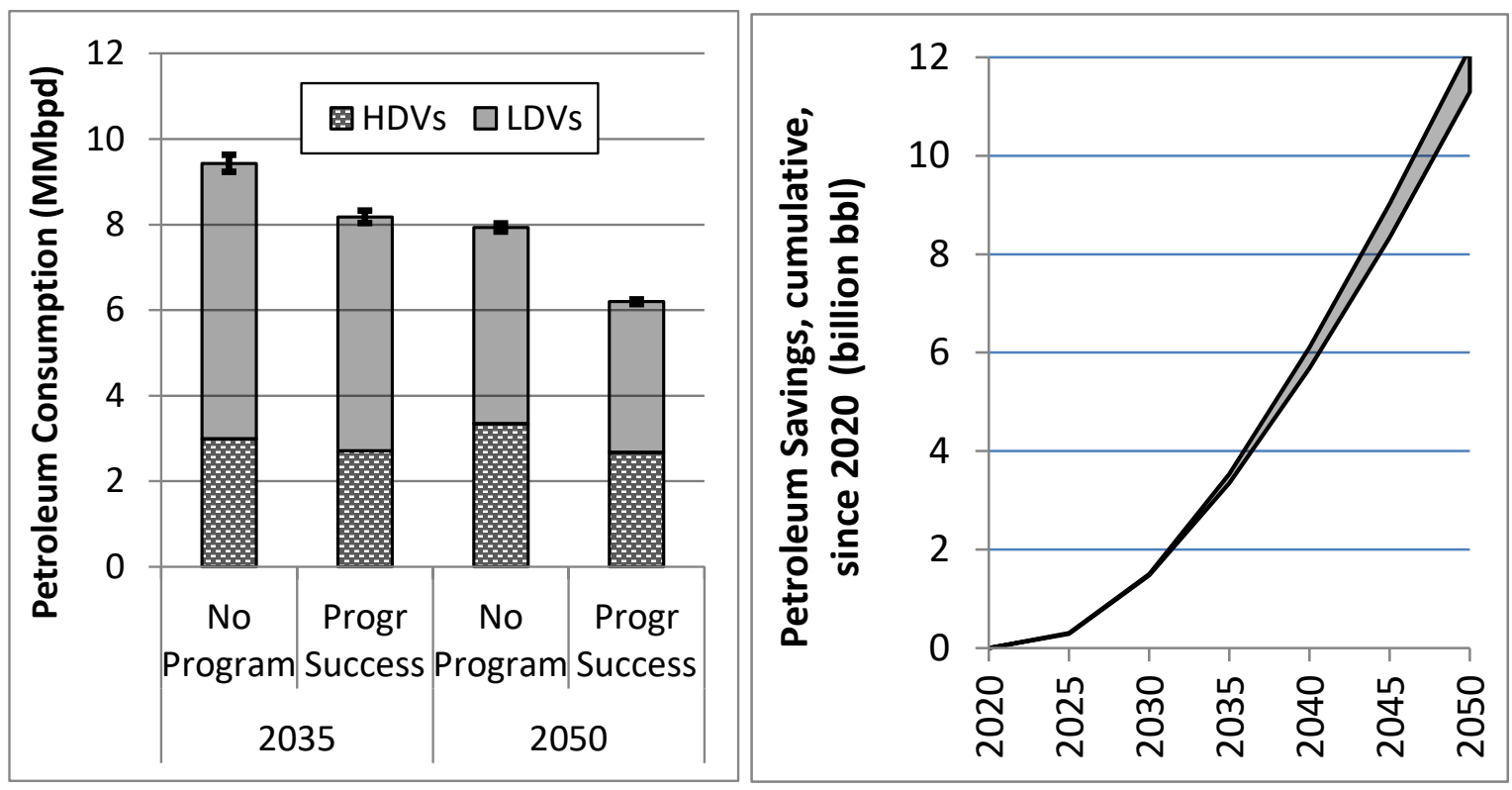

FIGURE 3-2 Estimated On-road Petroleum Consumption under the No Program and Program Success Cases in 2035 and 2050 (left) and Estimated Cumulative Petroleum Savings Attributed to VTO Technology Programs (right) (Uncertainty bars represent the ranges of estimates from different vehicle choice models.)

In 2025, the estimated petroleum reduction for LDVs is $0.32-0.33 \mathrm{MMbpd}$; in 2035 , the estimated petroleum reduction is $0.91-1.02 \mathrm{MMbpd}$; and in 2050, the estimated petroleum reduction reaches $1.02-1.10 \mathrm{MMbpd}$. To put these estimated reductions in petroleum use in context, in 2017, LDVs in the U.S. consumed 8.3 MMbpd of petroleum (Davis and Boundy, 2020). Petroleum savings in million barrels per day have the energy content of $1 \mathrm{MMbpd}=$ 1.916 quadrillion Btu/yr (based on 125,000 Btu/gal and 42 gal/barrel).

Reductions in petroleum usage by HTs due to VTO technologies are expected to grow from 0.02 MMbpd in 2025, to 0.29 MMbpd in 2035, to 0.68 MMbpd by 2050. To put these values in context, HTs in the U.S. consumed 3.0 MMbpd of petroleum in 2017 (Davis and Boundy, 2020).

Program Success is estimated to reduce cumulative petroleum consumption by both LDVs and HTs between 2020 and 2050 by 11.3 to 12.2 billion barrels, representing $11 \%$ to $12 \%$ of cumulative consumption in the No Program case. 


\subsection{ECONOMIC BENEFITS}

\subsubsection{Consumer Fuel Economy}

Fuel economy for consumers and businesses is improved through successful implementation of VTO technology. Improving fuel economy offers benefits to consumers, who pay lower prices for fuel and transportation-dependent commodities. Figure 3-3 shows estimated fuel economy for LDVs and HTs. Fuel economy is explored in greater depth at both the vehicle and fleet level in Appendix A for LDVs and in Appendix B for HTs.

The fuel economy improvements shown in Figure 3-4 and in Table 3-1 are large, with adjusted, combined city/highway fuel economy of new LDVs potentially increasing by as much as $26 \%$ by 2035 (relative to the No Program case), implying greatly reduced consumer spending on fuel. Likewise, large improvements in HT fuel economy (18\% increase in new-HT fuel economy by 2035) imply savings on goods transported by truck. In addition to these savings, increased average U.S. fuel economy means that vehicle drivers use fuel more efficiently, depending less on large amounts of petroleum fuel.
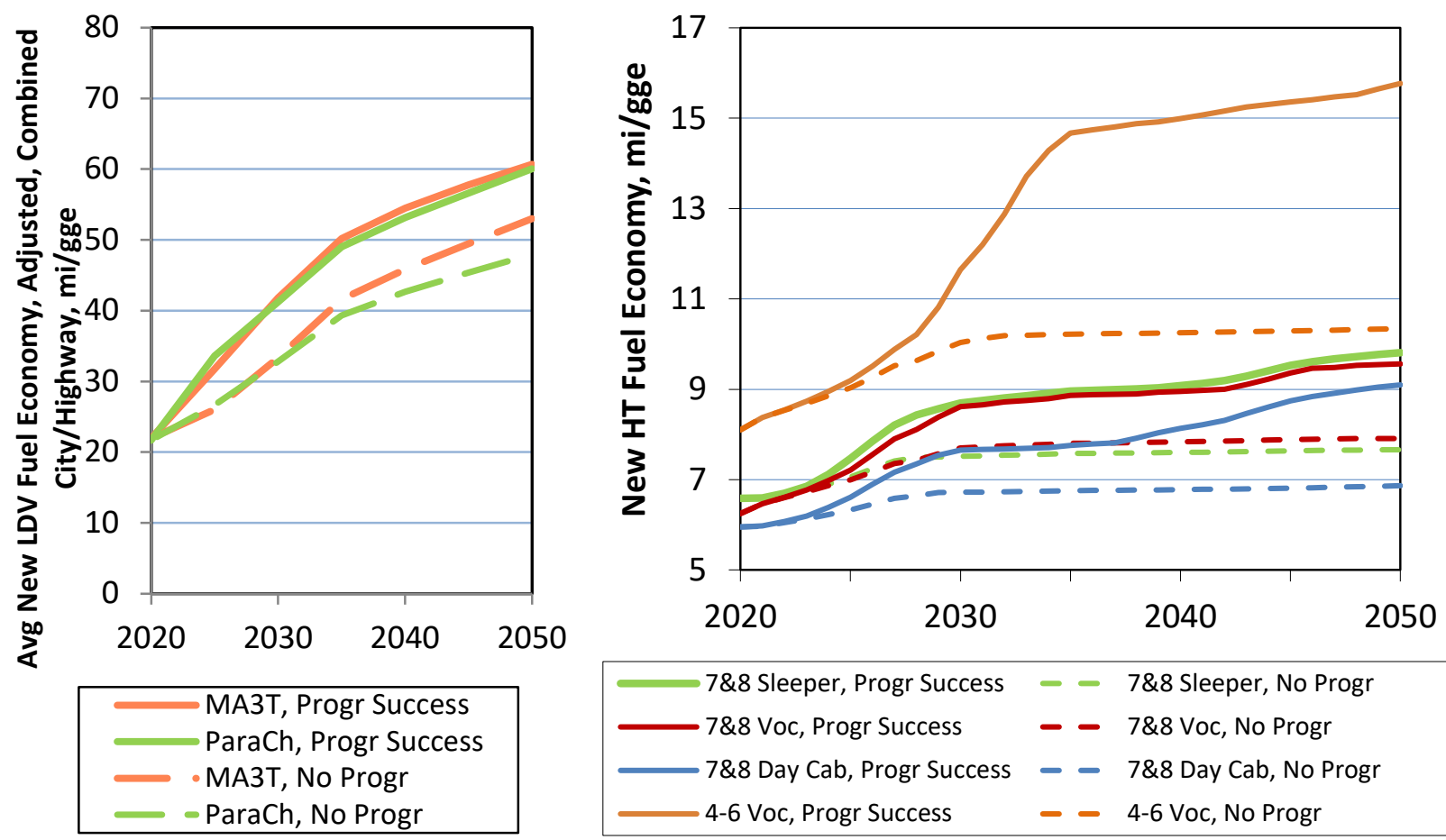

FIGURE 3-3 Fleet-averaged Fuel Efficiency through 2050 for LDVs (left) and HTs (right) for the Program Success and No Program Cases 


\subsubsection{LDV Levelized Cost of Driving}

The levelized cost of driving (LCD) is a measure of typical consumer expenditures per mile driven for a vehicle and the fuel purchased over a period of interest. The LCD was calculated for the drivetrains simulated for years 2025 and 2035 for the No Program and Program Success cases. The LCD is calculated as the ratio of the sum of the vehicle price and the present value of fuel consumed during operation, to the miles driven in that time frame.

$$
L C D=\frac{P_{V e h}+P V\left(C_{F u e l}\right)}{\sum_{i=1}^{N}(V M T / y r)_{i}},
$$

where

$P_{\text {Veh }}=$ Vehicle retail price equivalent,

$P V\left(C_{\text {Fuel }, i}\right)=$ Present value of fuel costs over $N$ years,

$N=$ Ownership period, and

$(V M T / y r)_{i}=$ Annual distance driven in year $i$

The LCD was calculated from the estimated retail price equivalent for each vehicle, and the estimated fuel expenditures over the miles driven during the period of vehicle ownership. Here, the period considered was 5 years. In accordance with the 2017 National Household Travel Survey (FHWA, undated), it was assumed that a vehicle would be driven an average of 13,500 mi per year during the first 5 years. Fuel expenditures were discounted at $7 \%$ annually, intermediate between the high discount rates (often over 20\%) at which some vehicle consumers discount future fuel savings (Greene, 2010; Greene et al., 2013) and a low discount rate (near zero) appropriate for discounting of social costs (OMB, 1992). LCDs reported here do not include costs such as depreciation (or resale value), operation costs such as maintenance and repair, or other costs such as taxes and fees. Most of these costs are likely to be similar for different drivetrain types, except perhaps for depreciation, maintenance, and repair. However, insufficient data are available to estimate reliable values for depreciation, maintenance, and repair costs for all the drivetrain types considered here, particularly PEVs and FCVs.

The LCD estimated for midsize cars in 2025 is shown in Figure 3-4, and for 2035 in Figure 3-5. Several drivetrains were analyzed, in $2015 \$$ per mile. A discount rate of $7 \%$ with a 5-year ownership period and an annual distance driven of 13,500 mi were assumed. In these figures, the LCD of the Program Success case is labeled "high," and the LCD of the No Program case is labeled "low," consistent with the naming of these scenarios by Islam et al. (2020), wherein the Program Success case assumed high technological progress and the No Program case assumed low technological progress. Program Success LCD values are lower than in the No Program case for all powertrains, and considerably lower for more advanced powertrains such as FCVs and BEVs. 


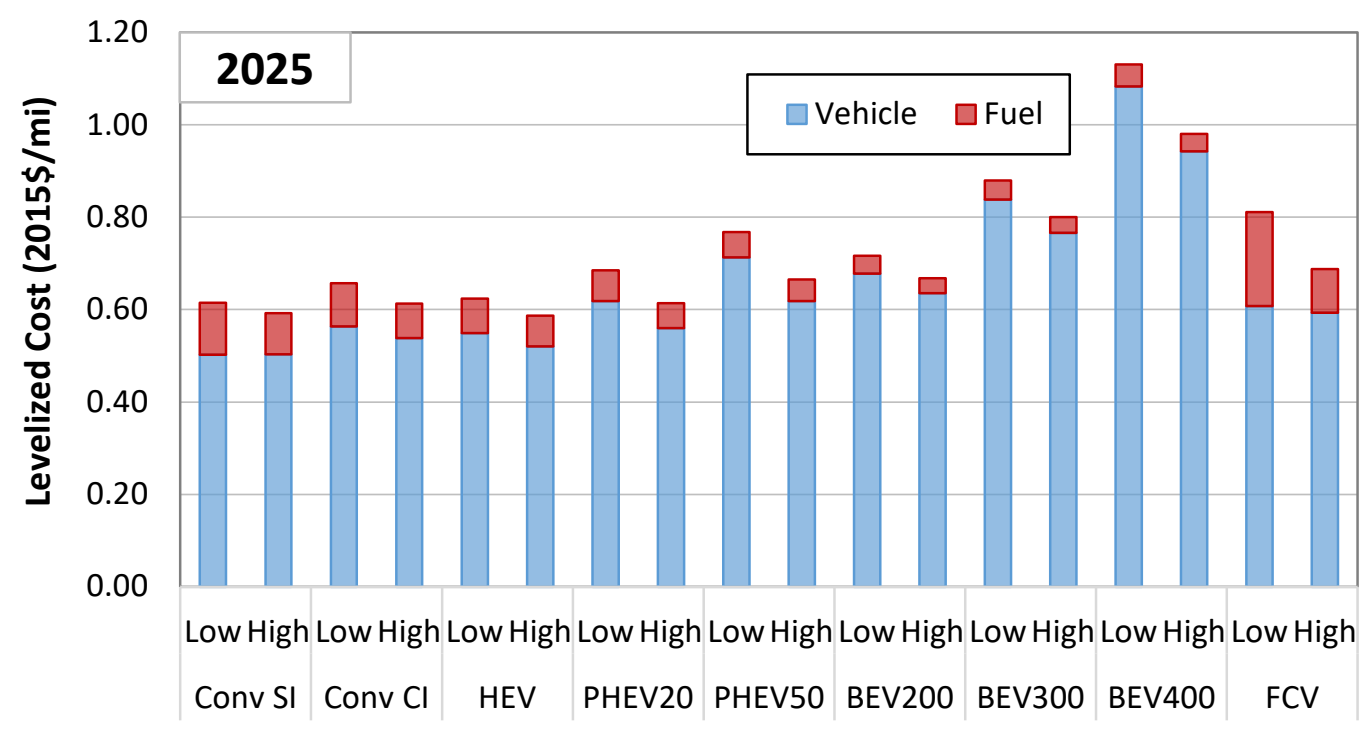

FIGURE 3-4 Estimated Levelized Cost of Driving a 2025 Midsize Car for Five Years (Costs labeled "high" are for Program Success, representing high technological progress, and those labeled "low" are for No Program, representing low technological progress. PVs of fuel costs shown assume a $7 \%$ discount rate.)

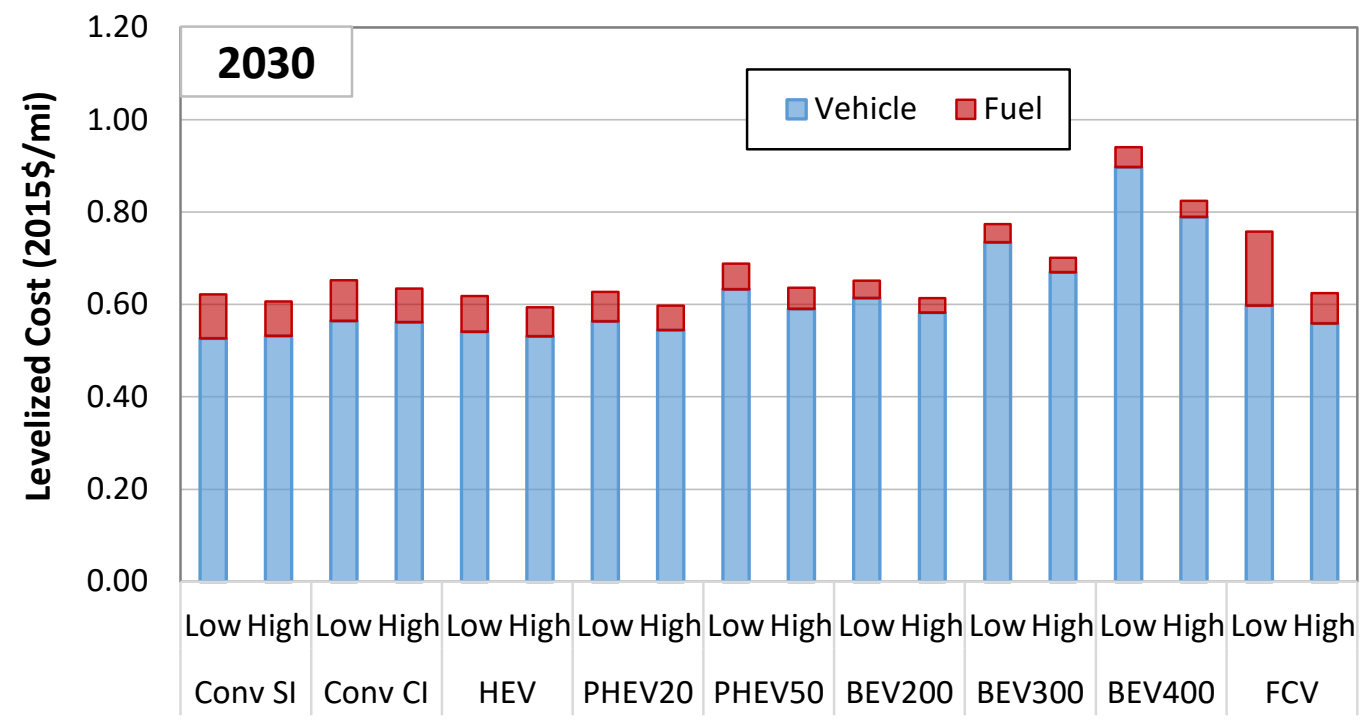

FIGURE 3-5 Estimated Levelized Cost of Driving a 2035 Midsize Car for Five Years (Costs labeled "high" are for Program Success, representing high technological progress, and those labeled "low" are for No Program, representing low technological progress. PVs of fuel costs shown assume a $7 \%$ discount rate.) 


\subsubsection{National-Level Vehicle Expenditures}

Results of LDV adoption modeling indicate that although advanced-technology vehicles may be somewhat more expensive at purchase, in some cases they will be less expensive, and the fuel savings are likely to be larger than the change in expenditures on new vehicles. For example, the potential reductions in annual fuel expenditures for LDVs in 2035 range from $\$ 49$ billion to $\$ 53$ billion (2015\$), while the potential decrease in new-LDV expenditures in the same year ranges from $\$ 27$ billion to $\$ 53$ billion (2015\$). These fuel-expenditure and new-vehicle savings are shown in Figure 3-6, in which savings are shown as negative values. As more advancedtechnology vehicles penetrate the market, vehicles become more expensive; however, the value of the fuel saved is much larger than the increase in spending on new vehicles. Uncertainty bars in Figure 3-6 represent the ranges of results across different vehicle choice models.

Results for HTs indicate a slight increase in vehicle expenditures with a much larger decrease in fuel expenditures. Estimated increases in annual new-vehicle expenditures for Class 4- 8 trucks and reductions in annual fuel expenditures by the on-road stocks of these trucks are shown in Figure 3-7. Total increases in expenditures for new-vehicle purchases and reductions in annual fuel expenditures are given in Table 3-1.

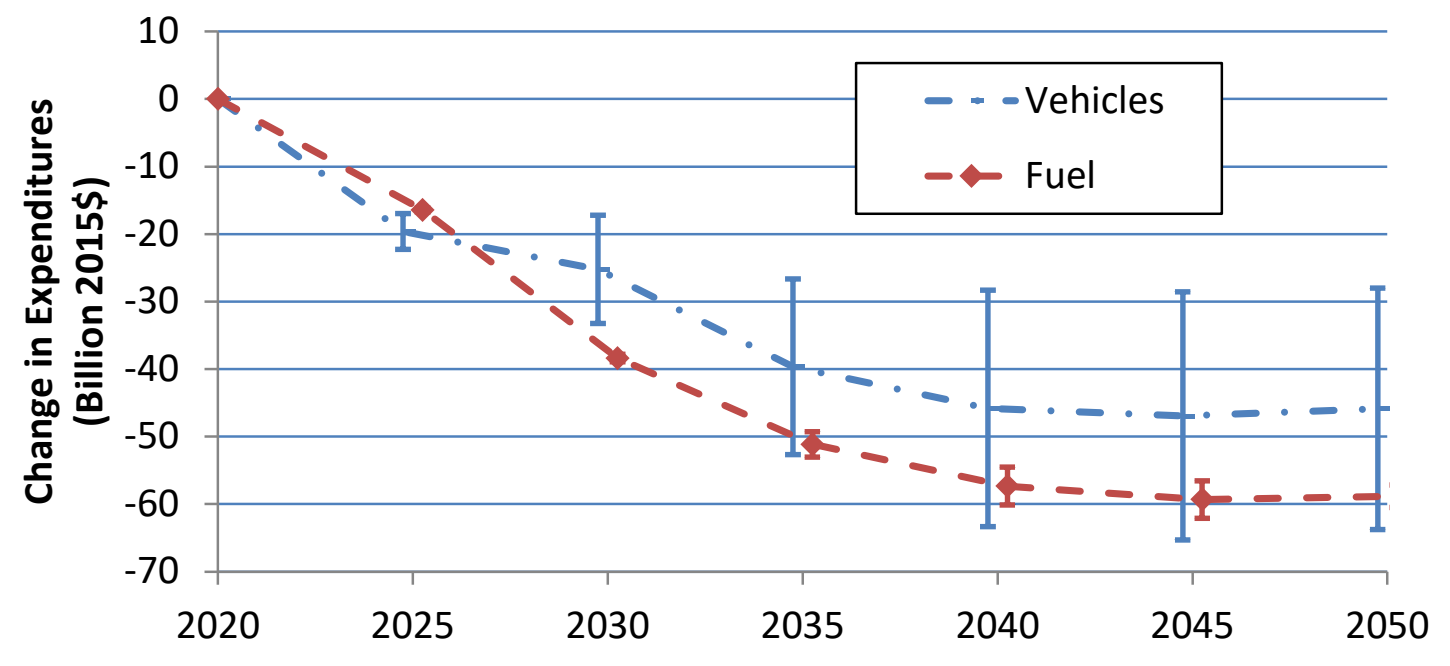

FIGURE 3-6 Differences in Annual National Consumer Expenditures for Vehicle Purchases and Fuel for LDVs through 2050 between the No Program and Program Success Cases (Reductions in expenditures are shown as negative. Uncertainty bars represent ranges of estimates for expenditures coming from two different vehicle choice models.) 


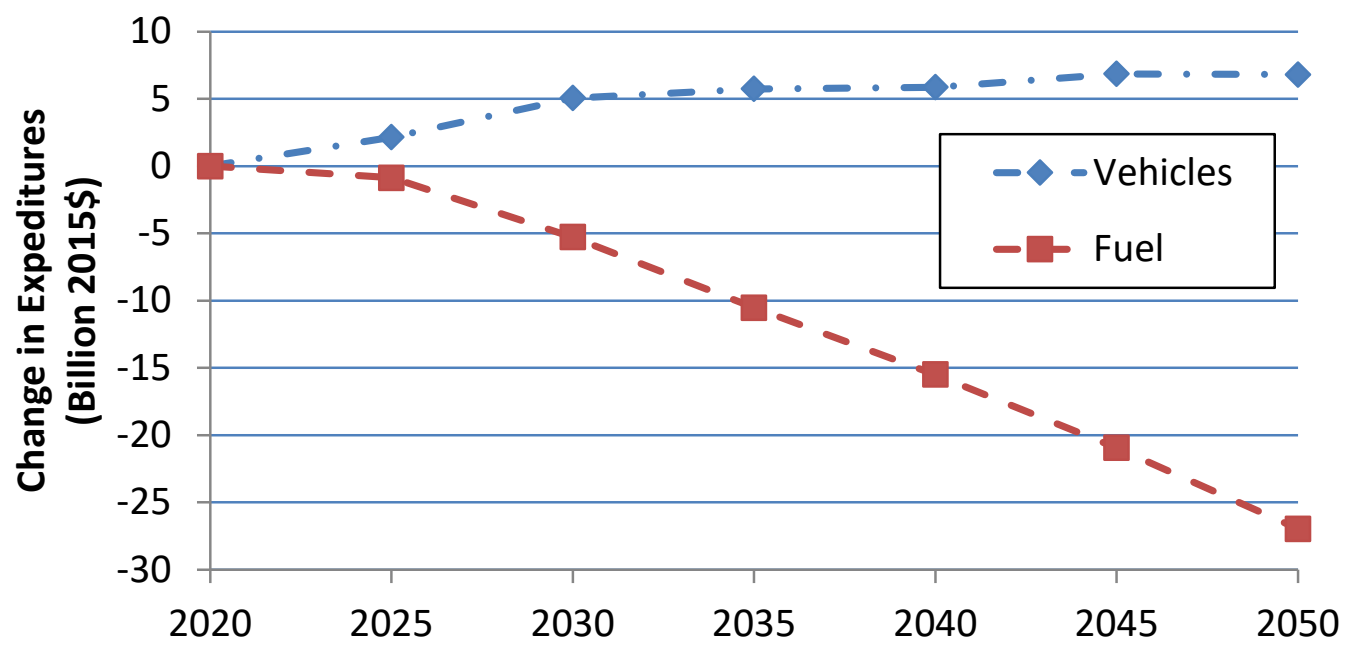

FIGURE 3-7 Differences in Annual National Costs of Vehicle Purchases and Fuel for HTs through 2050 between the No Program and Program Success Cases (The absence of uncertainty bars is due to using a single model for estimating the market penetration of HTs, though uncertainty in the results still exists.)

\subsection{ENVIRONMENTAL BENEFITS}

\subsubsection{Reductions in GHG Emissions}

The ranges of potential reductions in GHG emissions in 2035 and 2050 attributable to VTO research programs are shown in Figure 3-8, along with the range of cumulative GHG emission reductions since 2020. Again, since different LDV choice models gave different GHG results, ranges are shown. Emission reductions were estimated from the calculated changes in fuel used (including gasoline, diesel, electricity, and hydrogen) and the GHG intensity of each fuel, as described in Section 2, Appendix A, and Appendix B. Although there is uncertainty in these results, it is clear that successful implementation of VTO technologies can significantly reduce petroleum consumption and GHG emissions.

The estimated annual GHG emission benefit in 2035 is up to $232 \mathrm{MMt}$ of $\mathrm{CO}_{2}$-eq, as shown in Table 3-1 and Figure 3-8. Ranges shown reflect uncertainty in LDV market adoption (from using two market-penetration models) and in the future GHG intensity of electricity and hydrogen (as discussed in Section 2). These GHG reductions are substantial and will help the nation move toward a lower GHG total in 2035. By 2050, GHG reductions can be as high as $388 \mathrm{MMt}$ of $\mathrm{CO}_{2}$-eq per year. Compared with a national 2005 baseline of 7,379 MMt (EPA, 2016), this is potentially a $5 \%$ reduction attributable to VTO programs. The cumulative reduction in GHG emissions between 2020 and 2050 due to Program Success is estimated to be 5,260 to $6,570 \mathrm{MMt} \mathrm{CO}_{2}$-eq, which is up to $14 \%$ of the No Program cumulative emissions of 47,200 $\mathrm{MMt} \mathrm{CO}_{2}$-eq in 2050. 

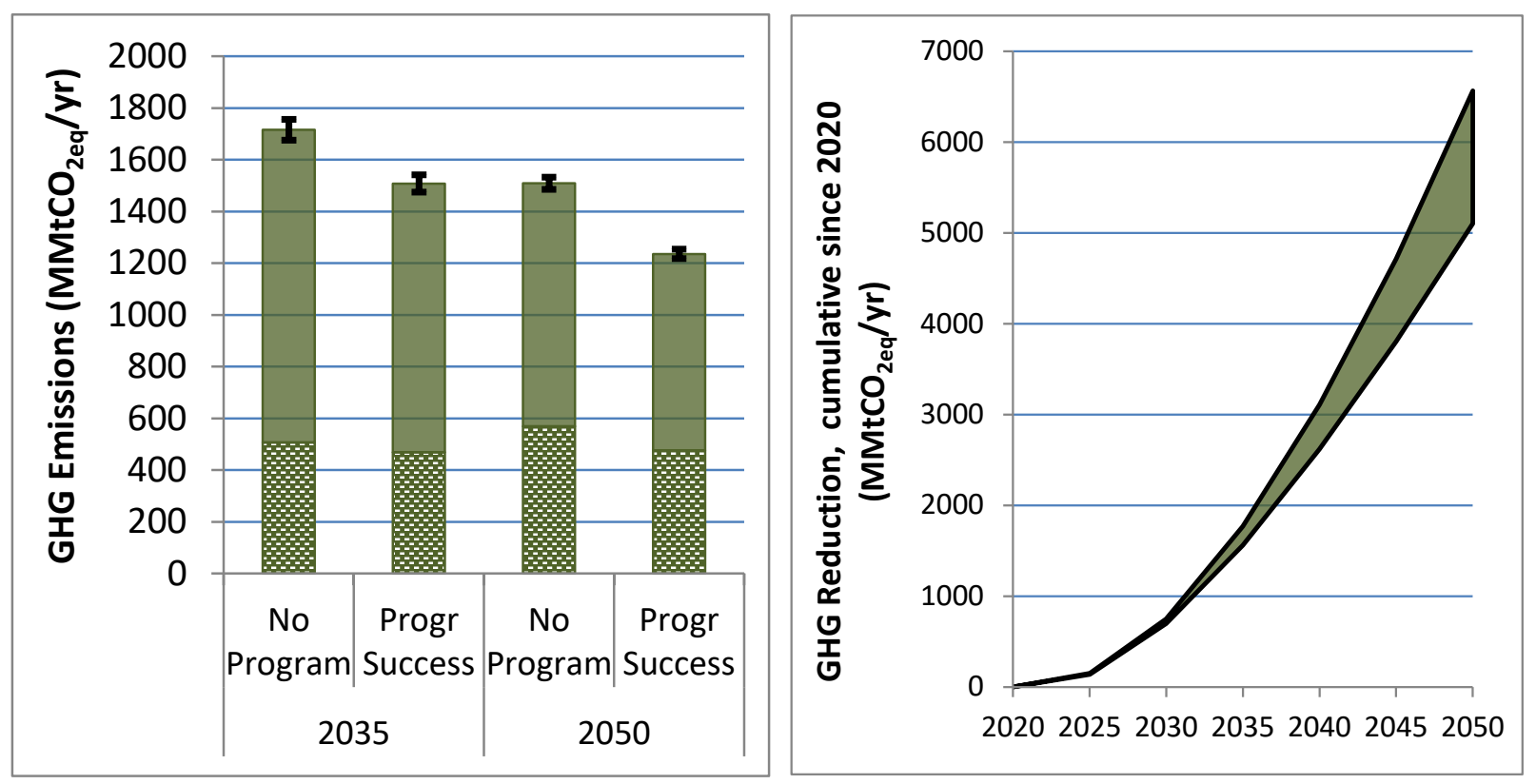

FIGURE 3-8 Estimated GHG Emissions under the No Program and Program Success Cases in 2035 and 2050 (left) and Estimated Cumulative GHG Reductions Attributed to VTO Technology Programs after 2020 (right) 
This page left intentionally blank. 


\section{CONCLUSIONS}

New technologies whose development is supported by VTO can be used to improve the vehicles that will be manufactured over the coming decades, from both a cost-effectiveness and a fuel-economy perspective. Research in advanced-vehicle technologies could have significant economic value in the U.S. transportation sector; help consumers and businesses save money; and reduce GHG emissions. Comparing the estimated benefits of successfully developing and implementing these technologies (the Program Success case) relative to the base case (the No Program case) quantifies the benefits of this government investment.

Results for the Program Success case indicate that by 2035, the average fuel economy of on-road LDV stock could be $18 \%$ to $19 \%$ higher than in the No Program case. In addition, average on-road fuel economies for HT stock in the same year could be as much as $8 \%$ higher. The resulting petroleum savings in 2035 were estimated to be as high as $1.3 \mathrm{MMbpd}$, and reductions in GHG emissions were estimated to be as high as $232 \mathrm{MMt}$ of $\mathrm{CO}_{2}$-eq per year. Such petroleum reductions result in significant reductions in fuel expenditure for both LDVs and HTs, totaling approximately $\$ 60$ billion annually by 2035 .

By 2050 , these benefits are calculated to increase to $\$ 84$ billion in annual fuel savings, and to reduce GHG emissions by as much as $388 \mathrm{MMt} \mathrm{CO}_{2}$-eq per year. Considering cumulative benefits from 2020 to 2050, a cumulative reduction of up to 12 billion barrels of oil and a cumulative reduction in GHG emissions of up to 6,570 $\mathrm{MMt}_{\text {of }} \mathrm{CO}_{2}$-eq are possible with successful development of VTO technologies. By comparison, in the No Program case, cumulative petroleum consumption between 2020 and 2050 is estimated to be 102 to 105 billon bbl. 


\section{REFERENCES}

21CTP (21 ${ }^{\text {st }}$ Century Truck Partnership), 2019, "21st Century Truck Partnership Research Blueprint,” February, U.S. Department of Energy, https://www.energy.gov/eere/vehicles/ downloads/21st-century-truck-partnership-research-blueprint, accessed July 28, 2020.

Argonne (Argonne National Laboratory), 2019a, "VISION 2019 Model," https://www.anl.gov/es/vision-model, accessed July 27, 2020.

Argonne, 2019b, “Argonne GREET Model,” https://greet.es.anl.gov, accessed June 11, 2020.

Argonne, undated, “Autonomie,” Argonne National Laboratory, Lemont, IL, http://www.autonomie.net/index.html, accessed June 11, 2020.

Boyd, S., 2018, "Batteries and Electrification R\&D Overview," presented at U.S. Department of Energy VTO Annual Merit Review and Peer Evaluation, Washington, DC.

Bunker, B., 2015, Derived 5-cycle Coefficients for 2017 and Later Model Years, U.S. Environmental Protection Agency, National Vehicle and Fuel Emission Laboratory, CD-15-15 (LDV/LDT/ICI/LIMO), June 22.

Commercial Truck Trader, 2019, https://www.commercialtrucktrader.com/, accessed June 16, 2020 .

Davis, S.C., and R.G. Boundy, 2020, Transportation Energy Data Book, Edition 38, Oak Ridge National Laboratory, Oak Ridge, TN, ORNL/TM-2019/1333, https://tedb.ornl.gov/, accessed July 27, 2020.

DOE (U.S. Department of Energy), 2017, Lightweight Materials 2016 Annual Report, U.S. Department of Energy, Washington, D.C., DOE/EE-1533, https://www.osti.gov/biblio/ 1416107-fy2016-lightweight-materials-annual-progress-report, accessed July 29, 2020.

DOE, 2018, Clean Cities Alternative Fuel Price Report, April 2018," https://afdc.energy.gov/ files/u/publication/alternative_fuel_price_report_april_2018.pdf, accessed August 13, 2020.

DOE, 2019, “Alternative Fuels Data Center,” https://afdc.energy.gov/, accessed August 13, 2020 .

DOE EERE (Office of Energy Efficiency and Renewable Energy), 2020, 2019 Annual Merit Review Report, Vehicle Technologies Office, February, https://www.energy.gov/eere/ vehicles/downloads/2019-annual-merit-review-report, accessed July 21, 2020. 
EIA (U.S. Energy Information Administration), 2019, Annual Energy Outlook 2019: With Projections to 2050, Office of Integrated Analysis and Forecasting, Energy Information Administration, U.S. Department of Energy, Washington, D.C., https://www.eia.gov/outlooks/archive/aeo19/pdf/aeo2019.pdf, accessed July 27, 2020.

EPA (U.S. Environmental Protection Agency), 2016, Inventory of U.S. Greenhouse Gas Emissions and Sinks: 1990-2014, U.S. Environmental Protection Agency, EPA-430-R-16-002, April, https://www.epa.gov/ghgemissions/inventory-us-greenhouse-gas-emissions-and-sinks1990-2014, accessed Aug. 31, 2017.

EPA and NHTSA (National Highway Traffic Safety Administration), 2016, Greenhouse Gas Emissions Standards and Fuel Efficiency Standards for Medium-and Heavy-Duty Engines and Vehicles - Phase 2 Regulatory Impact Analysis, EPA-420-R-16-900, August, https://www.epa.gov/regulations-emissions-vehicles-and-engines/final-rule-phase-2-greenhousegas-emissions-standards-and, accessed July, 2020.

FHWA (Federal Highway Administration), undated, "National Household Travel Survey," https://nhts.ornl.gov, accessed Aug. 14, 2020.

Greene, D.L., 2010, How Consumers Value Fuel Economy: A Literature Review, Environmental Protection Agency, Washington, D.C., EPA-410-10-008, https://cfpub.epa.gov/si/ si_public_file_download.cfm?p_download_id=499454, accessed July 29, 2020.

Greene, D.L., D.H. Evans, and J. Hiestand, 2013, "Survey Evidence on the Willingness of U.S. Consumers to Pay for Automotive Fuel Economy," Energy Policy, 61, 1539-1550.

Islam, E., A. Moawad, N. Kim, and A. Rousseau, 2017, An Extensive Study on Sizing, Energy Consumption and Cost of Advanced Vehicle Technologies, Argonne National Laboratory, Lemont, IL, ANL/ESD-17/17, August, https://www.osti.gov/servlets/purl/1463258, accessed July 27, 2020.

Islam, E., A. Moawad, N. Kim, and A. Rousseau, 2020, Energy Consumption and Cost Reduction of Future Light-Duty Vehicles through Advanced Vehicle Technologies: A Modeling Simulation Study Through 2050, Argonne National Laboratory, Lemont, IL, ANL/ESD-19/10, June, https://www.osti.gov/biblio/1647165-energy-consumption-cost-reduction-future-lightduty-vehicles-through-advanced-vehicle-technologies-modeling-simulation-study-through, and accompanying data files, https://www.autonomie.net/publications/fuel_economy report.html, accessed October 6, 2020.

Lin, Z., 2019, “Transportation Energy Evolution Modeling (TEEM) Program,” presented at U.S. Department of Energy Vehicle Technologies Office Annual Merit Review and Peer Evaluation, Washington, D.C., June 13, https://www.energy.gov/eere/vehicles/downloads/transportation-energy-evolution-modelingteem-program, accessed October 7, 2020. 
Lin, Z., and D.L. Greene, 2010, “A Plug-in Hybrid Consumer Choice Model with Detailed Market Segmentation," presented at Transportation Research Board 2010 Annual Meeting, TRB 89th Annual Meeting Compendium of Papers, Transportation Research Board, Washington, D.C., http://pubsindex.trb.org/view.aspx?id=910112, accessed July 27, 2020.

Lin, Z., and D.L. Greene, 2011, "Promoting the Market for Plug-In Hybrid and Battery Electric Vehicles: The Role of Recharge Availability," Transportation Research Record, 2252, 49-56, https://journals.sagepub.com/doi/10.3141/2252-07, accessed July 27, 2020.

Manley, D., R. Levinson, G. Barter, and T. West, 2015, "ParaChoice: Parametric Vehicle Choice Modeling," presented at U.S. Department of Energy Vehicle Technologies Office Annual Merit Review and Peer Evaluation, Washington, D.C., June 11, http://energy.gov/eere/ vehicles/downloads/vehicle-technologies-office-merit-review-2015-parachoice-parametricvehicle, accessed Aug. 31, 2017.

NREL (National Renewable Energy Laboratory), 2012, Renewable Electricity Futures Study, Vols. 1-4, Hand, M.M.; Baldwin, S.; DeMeo, E.; Reilly, J.M.; Mai, T.; Arent, D.; Porro, G.; Meshek, M.; and Sandor, D., eds., National Renewable Energy Laboratory, Golden, CO, NREL/TP-6A20-52409, https://www.nrel.gov/docs/fy13osti/52409-ES.pdf, accessed July $14,2020$.

OMB (Office of Management and Budget), 1992, Guidelines and Discount Rates for BenefitCost Analysis of Federal Programs, Circular A-94 Revised, Office of Management and Budget, Washington, D.C., https://www.whitehouse.gov/sites/whitehouse.gov/files/omb/ circulars/A94/a094.pdf/, accessed July 27, 2020.

Proctor, C., 2019, "ParaChoice Model," presented at U.S. Department of Energy Vehicle Technologies Office Annual Merit Review and Peer Evaluation, Washington, D.C., June 13, https://energy.gov/eere/vehicles/downloads/parachoice-model, accessed July 27, 2020.

Rogozhin, A., M. Gallaher, G. Helfand, and W. McManus, 2010, "Using Indirect Cost Multipliers to Estimate the Total Cost of Adding a New Technology in the Automobile Industry," International Journal of Production Economics 124, 360-368.

Singh, G., 2018, “Overview: Advanced Combustion Systems and Fuels R\&D,” presented at U.S. Department of Energy VTO Annual Merit Review and Peer Evaluation, Washington, DC, https://www.energy.gov/eere/vehicles/downloads/vehicle-technologies-office-merit-review2018-doe-advanced-combustion, accessed August 13, 2020.

Stephens, T., C.H. Taylor, J.S. Moore, and J. Ward, 2016, Vehicle Technologies and Fuel Cell Technologies Program Prospective Benefits Assessment Report for Fiscal Year 2016, Argonne National Laboratory, Lemont, IL, ANL/ESD-16/2, http://www.osti.gov/scitech/biblio/1250457vehicle-technologies-fuel-cell-technologies-program-prospective-benefits-assessment-reportfiscal-year, accessed July 29, 2020. 
Stephens, T.S., A. Birky, and D. Gohlke, 2017, Vehicle Technologies and Fuel Cell Technologies Office Research and Development Programs: Prospective Benefits Assessment Report for Fiscal Year 2018, Argonne National Laboratory, Lemont, IL, ANL/ESD-17/22, November, https://www.osti.gov/scitech/biblio/1410412-vehicle-technologies-fuel-celltechnologies-office-research-development-programs-prospective-benefits-assessment-reportfiscal-year, accessed August 13, 2020.

Stephens, T.S., R. Vijayagopal, M. Dwyer, A. Birky, and A. Rousseau, 2019, Vehicle Technologies and Fuel Cell Technologies Office Research and Development Programs: Prospective Benefits Assessment for Medium- and Heavy-duty Vehicles, Argonne National Laboratory, Lemont, IL, ANL-19/58, December, https://www.osti.gov/biblio/1618829-vehicletechnologies-fuel-cell-technologies-office-research-development-programs-prospective-benefitsassessment-medium-heavy-duty-vehicles, accessed July 29, 2020.

Truck Paper, 2019, https://www.truckpaper.com/, accessed June 16, 2020.

Vijayagopal, R, D. Nieto Prada, and A. Rousseau, 2019, Fuel Economy and Cost Estimates for Medium- and Heavy-Duty Trucks, Argonne National Laboratory, Lemont, IL, ANL/ESD-19/8, December, https://www.autonomie.net/pdfs/ANL-

MDHD\%20Vehicle\%20Simulation\%20Report.pdf, accessed October 6, 2020.

VTO (Vehicle Technologies Office, U.S. Department of Energy), 2013, Workshop Report: Trucks and Heavy-duty Vehicles Technical Requirements and Gaps for Lightweight and Propulsion Materials, Feb., https://www.energy.gov/sites/prod/files/2014/03/f13/wr_trucks hdvehicles.pdf, accessed Aug 17, 2020.

Vyas, A., D. Santini, and R. Cuenca, 2000, Comparison of Indirect Cost Multipliers for Vehicle Manufacturing, Technical Memorandum, ANL/ES/RP-101898, Argonne National Laboratory, Lemont, IL, April. 


\section{APPENDIX A: LIGHT-DUTY VEHICLE MODEL INPUTS AND OUTPUTS}

\section{A.1 INPUTS OF LIGHT-DUTY VEHICLE (LDV) VEHICLE CHOICE MODELING}

Analyzing market adoption using more than one model gives a range of possible outcomes and permits examination of the effects of these differences on fuel use and greenhouse gas (GHG) emissions. These two models were developed with different assumptions, and each represents the LDV market slightly differently:

- In the Market Acceptance of Advanced Automotive Technologies ( $\left.\mathrm{MA}^{3} \mathrm{~T}\right)$ model, consumers are segmented by attitude toward risk (early adopter, early majority, and late majority), driving pattern, population density, availability of electric charging at home and at work, and state of residence. $\mathrm{MA}^{3} \mathrm{~T}$ models total LDV sales and sales shares of each size class endogenously.

- The ParaChoice model is based on the $\mathrm{MA}^{3} \mathrm{~T}$ model, with some simplifications, but is integrated with an energy-sector model that estimates hydrogen prices endogenously. For this analysis, parameters governing hydrogen prices were set to nearly match the Hydrogen and Fuel Cell Technologies Office (HFTO)supplied prices.

Both models give estimates of future sales shares by drivetrain technology: Conv sparkignition (SI), Conv compression-ignition (CI), hybrid electric vehicle (HEV), plug-in hybrid electric vehicles (PHEVs) with on-road charge-depleting ranges of 20 and 50 miles, battery electric vehicles (BEVs) with on-road ranges of 200, 300, and 400 miles, and hydrogen fuel cell vehicles (FCVs). In the $\mathrm{MA}^{3} \mathrm{~T}$ model, Midsize cars and Compact SUVs (as simulated in Autonomie) were assigned to the car size class, and Autonomie results for Midsize SUVs and Pickups were assigned to the light-truck class. In ParaChoice, Compact and Midsize cars and Compact SUVs were included in the car size class, and Midsize SUVs and Pickups were included in the light-truck class. Detailed discussions about these models and their inputs have been presented by Lin (2019), Proctor (2019), and Stephens et al. (2017).

Future fuel prices were assumed to be those in the AEO 2019 Reference Case (EIA 2019). Future hydrogen prices for the No Program case were supplied by HFTO. Whereas the ParaChoice model used endogenously estimated hydrogen prices, parameters in the model were chosen to match the HFTO-supplied prices in 2015 and 2050, and differed slightly in other years. The assumed fuel prices, in 2015 dollars per gallon gasoline equivalent (gge), are shown in Figure A-1.

Biofuel was not modeled, except for the ethanol content in gasoline and E85. Flex-fuel vehicles were not modeled explicitly in vehicle choice models, but a small fraction of the Conv SI vehicles were assumed to use E85. Fuel prices were assumed to be independent of fuel demand (no price elasticity). 


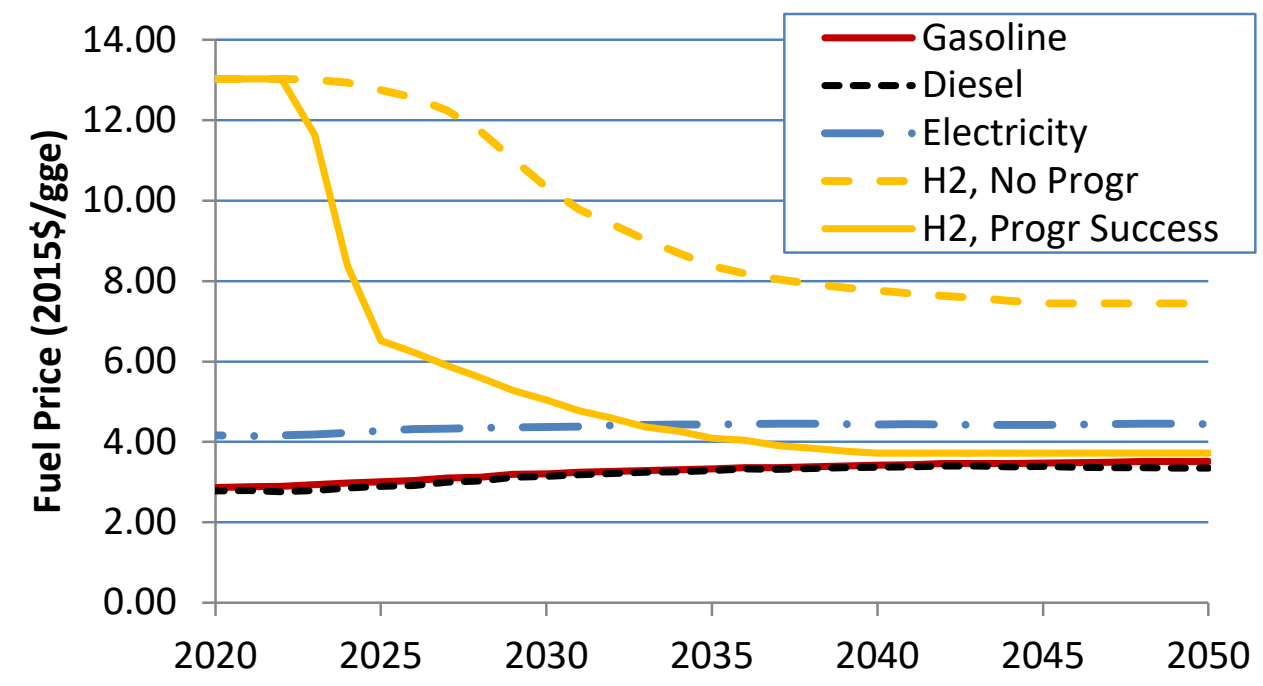

FIGURE A-1 Fuel Prices Used for Modeling, in 2015\$ per gge (1 gge = 125,000 Btu)

\section{A.2 COMPARISON OF LDV MARKET PENETRATION}

New LDV sales shares for the No Program and Program Success cases were estimated by drivetrain technology for 2012-2050. Sales shares modeled using the $\mathrm{MA}^{3} \mathrm{~T}$ and ParaChoice models described in Section 2.1.2 are presented in Tables A-1 and A-2, respectively. Resulting on-road LDV stocks by drivetrain type calculated using the stock model in VISION, using the sales shares outputs of each model, are shown in Figures A-2 and A-3, respectively.

The two LDV choice models using the same inputs (based directly on the VTO goals) for the Program Success case and inputs established for the No Program case give quantitatively different market-penetration results, but show similar market penetration by advancedtechnology vehicles. The fuel economy of the LDV fleet is estimated to increase with significant reductions in petroleum use and GHG emissions as a result of not only improvements in vehicle efficiency, but also increases in the share of vehicles that use little or no petroleum. 
TABLE A-1 LDV Market-penetration Estimates for the No Program and Program Success Cases from the $\mathrm{MA}^{3} \mathrm{~T}$ Model

\begin{tabular}{|c|c|c|c|c|c|c|c|c|}
\hline \multirow[b]{2}{*}{ Drivetrain Type } & \multicolumn{4}{|c|}{ No Program (\%) } & \multicolumn{4}{|c|}{ Program Success (\%) } \\
\hline & 2025 & 2030 & 2040 & 2050 & 2025 & 2030 & 2040 & 2050 \\
\hline SI Conv & 79.2 & 69.5 & 46.4 & 40.1 & 79.8 & 61.7 & 47.5 & 38.5 \\
\hline CI Conv & 0.0 & 0.0 & 0.0 & 0.0 & 0.0 & 0.0 & 0.0 & 0.0 \\
\hline HEV Gasoline & 18.1 & 19.6 & 18.7 & 18.1 & 16.3 & 21.7 & 15.5 & 17.1 \\
\hline PHEV20 & 0.2 & 0.4 & 1.1 & 2.6 & 0.3 & 0.5 & 0.8 & 1.4 \\
\hline PHEV50 & 1.0 & 4.8 & 19.9 & 19.1 & 2.3 & 8.4 & 12.3 & 12.7 \\
\hline BEV200 & 1.4 & 5.2 & 12.4 & 18.5 & 1.3 & 5.1 & 15.5 & 18.7 \\
\hline BEV300 & 0.0 & 0.1 & 0.1 & 0.2 & 0.1 & 0.2 & 0.4 & 0.7 \\
\hline BEV400 & 0.0 & 0.0 & 0.0 & 0.0 & 0.0 & 0.0 & 0.1 & 0.2 \\
\hline FCV & 0.1 & 0.3 & 1.3 & 1.4 & 0.1 & 2.5 & 8.0 & 10.7 \\
\hline
\end{tabular}

TABLE A-2 LDV Market-penetration Estimates for the No Program and Program Success Cases from the ParaChoice Model

\begin{tabular}{lrrrrrrrrrr}
\hline & \multicolumn{4}{c}{ No Program (\%) } & & \multicolumn{5}{c}{ Program Success (\%) } \\
\cline { 2 - 4 } \cline { 8 - 10 } Drivetrain Type & 2025 & 2030 & 2040 & 2050 & & 2025 & 2030 & 2040 & 2050 \\
\hline & & & & & & & & & \\
SI Conv & 67.1 & 45.8 & 25.7 & 24.7 & & 58.0 & 37.8 & 23.9 & 21.2 \\
CI Conv & 6.3 & 10.3 & 7.9 & 6.2 & & 7.6 & 8.3 & 6.2 & 5.3 \\
HEV Gasoline & 21.9 & 34.7 & 29.5 & 26.7 & & 32.4 & 41.6 & 28.6 & 24.5 \\
PHEV20 & 3.5 & 7.4 & 27.2 & 29.0 & & 1.5 & 8.7 & 25.7 & 24.6 \\
PHEV50 & 1.0 & 1.7 & 8.0 & 10.0 & & 0.4 & 3.1 & 10.9 & 10.9 \\
BEV200 & 0.2 & 0.2 & 1.1 & 1.8 & & 0.0 & 0.2 & 2.3 & 3.3 \\
BEV300 & 0.0 & 0.0 & 0.0 & 0.1 & & 0.0 & 0.0 & 0.1 & 0.7 \\
BEV400 & 0.0 & 0.0 & 0.0 & 0.0 & & 0.0 & 0.0 & 0.0 & 0.1 \\
FCV & 0.0 & 0.0 & 0.5 & 1.5 & & 0.0 & 0.2 & 2.2 & 9.4 \\
\hline
\end{tabular}



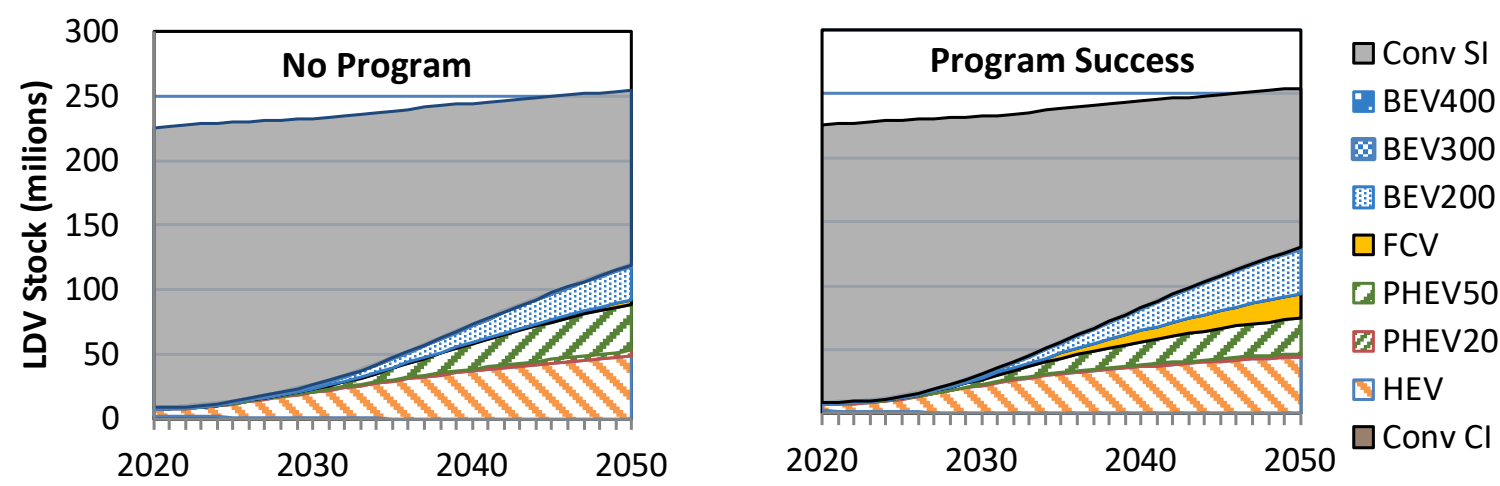

FIGURE A-2 LDV Stock by Powertrain Type for the No Program (left) and Program Success (right) Cases Modeled Using the $\mathbf{M A}^{3} \mathrm{~T}$ Model
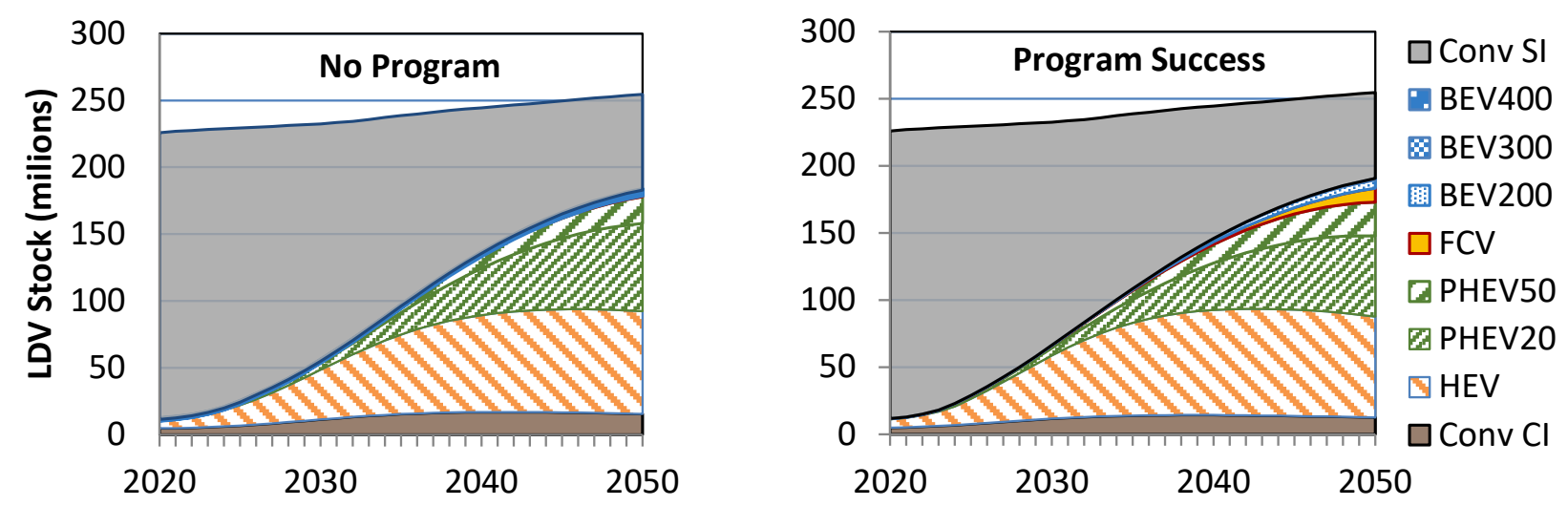

FIGURE A-3 LDV Stock by Powertrain Type for the No Program (left) and Program Success (right) Cases Modeled Using the ParaChoice Model

\section{A.3 LDV FUEL ECONOMY}

Vehicles in the Program Success case have higher fuel economy than those in the No Program case. The fuel economy values for each of the vehicles in this study are presented in detail in an Argonne National Laboratory report (Islam et al., 2020).

The fleet-averaged fuel economy of new LDVs in the Program Success and No Program cases depends on the market-share results from the ParaChoice and $\mathrm{MA}^{3} \mathrm{~T}$ vehicle choice models. Sales-weighted harmonic averages of adjusted, combined city/highway fuel economies were calculated from sales shares using on-road fuel economy degradation factors, with a city/highway vehicle miles traveled (VMT) weighting of $43 \% / 57 \%$. These averages are shown in Figure A-4 for new-vehicle sales in each year. Using modeled fuel economy values for new vehicles and the stock model in VISION, the on-road fleet-averaged fuel economies were calculated for both cases and are shown in Figure A-5. The fuel economy averages are significantly higher for Program Success than for No Program, owing both to efficiency 
improvements of vehicles and each powertrain type, and to increased market shares of vehicles with more efficient powertrains, such as PEVs and FCVs.

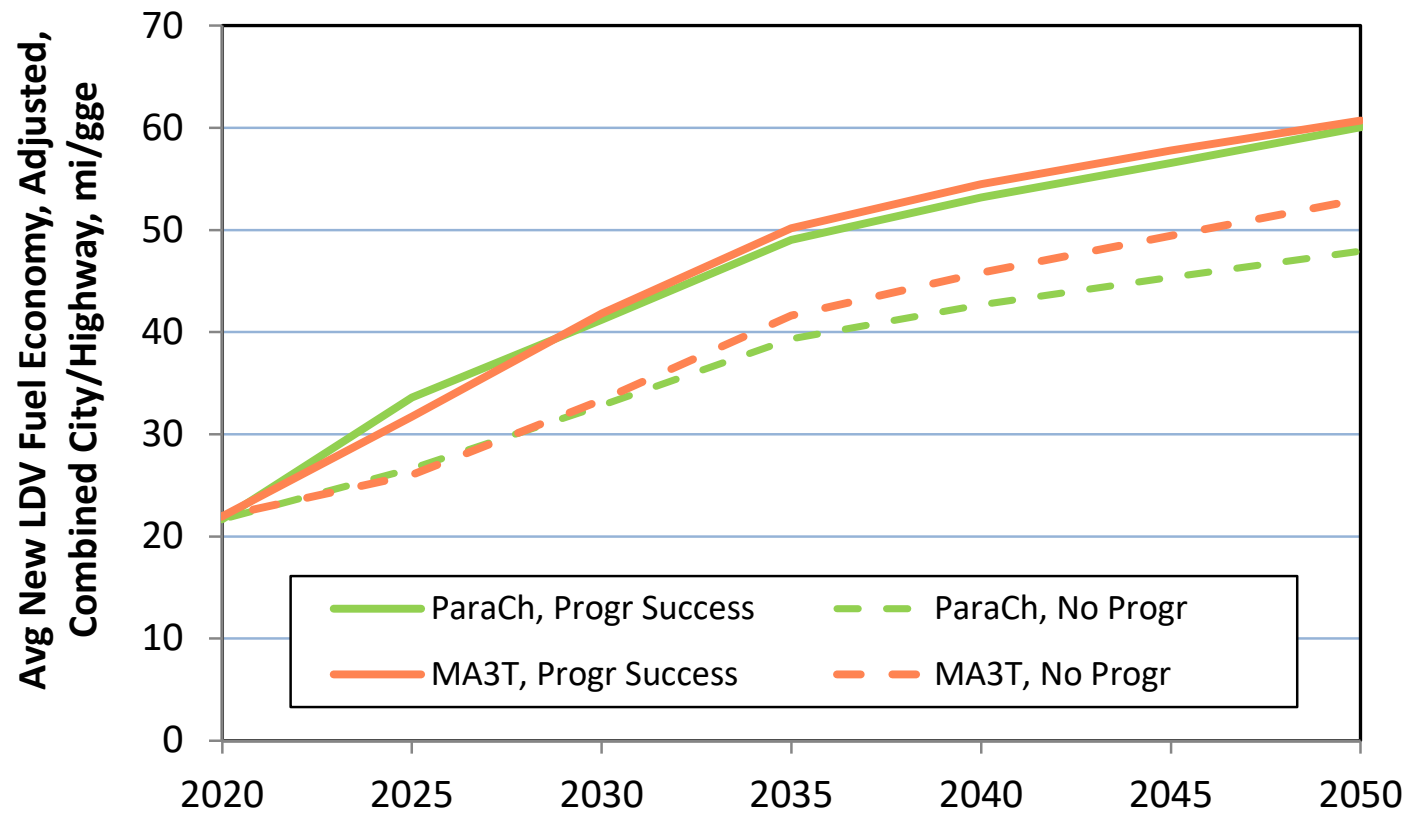

FIGURE A-4 Fleet-averaged Fuel Economies of New LDVs for the No Program (dashed lines) and Program Success (solid lines) Cases Based on Market Adoption Results from the Two LDV Choice Models 


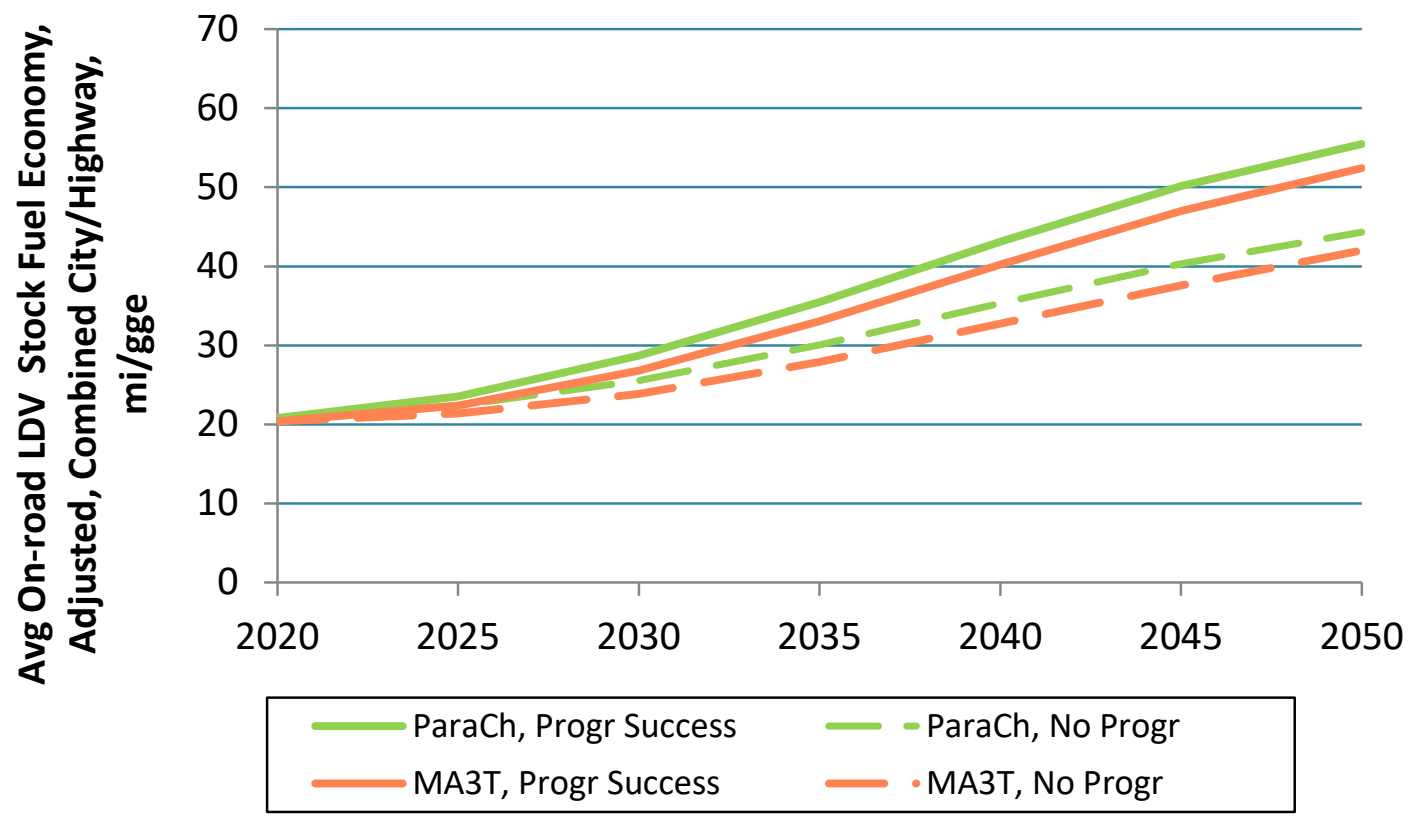

FIGURE A-5 Average Fuel Economies of On-road LDVs for the No Program (dashed lines) and Program Success (solid lines) Cases Based on Market Adoption Results from the Two LDV Choice Models

\section{A.4 REFERENCES}

EIA (U.S. Energy Information Administration), 2019, Annual Energy Outlook 2019: With Projections to 2050, Office of Integrated Analysis and Forecasting, Energy Information Administration, U.S. Department of Energy, Washington, D.C., https://www.eia.gov/outlooks/archive/aeo19/pdf/aeo2019.pdf, accessed July 27, 2020.

Islam, E., A. Moawad, N. Kim, and A. Rousseau, 2020, Energy Consumption and Cost Reduction of Future Light-Duty Vehicles through Advanced Vehicle Technologies: A Modeling Simulation Study Through 2050, Argonne National Laboratory, Lemont, IL, ANL/ESD-19/10, https://www.autonomie.net/pdfs/ANL-MDHD\%20Vehicle\%20Simulation\%20Report.pdf, accessed July 27, 2020.

Lin, Z., 2019, "Transportation Energy Evolution Modeling (TEEM) Program," presented at U.S. Department of Energy Vehicle Technologies Office Annual Merit Review and Peer Evaluation, Washington, D.C., June 13, https://energy.gov/eere/vehicles/downloads/transportation-energyevolution-modeling-teem-program, accessed July 27, 2020.

Proctor, C., 2019, "ParaChoice Model," presented at U.S. Department of Energy Vehicle Technologies Office Annual Merit Review and Peer Evaluation, Washington, D.C., June 13, https://energy.gov/eere/vehicles/downloads/parachoice-model, accessed July 27, 2020. 
Stephens T.S., R.S. Levinson, A. Brooker, C. Liu, Z. Lin, A. Birky, and E. Kontou, 2017, Comparison of Vehicle Choice Models, Argonne National Laboratory, Lemont, IL, ANL/ESD$17 / 19$, October. 


\section{APPENDIX B: HEAVY-TRUCK MARKET-PENETRATION MODELING}

\section{B.1 HEAVY-TRUCK MARKET PENETRATION; PROGRAM SUCCESS SCENARIO}

Results of market-penetration modeling of advanced-technology heavy trucks (HTs) in the Program Success case are given in Table B-1 as fractions of total vehicle miles traveled (VMT) by new trucks in a calendar year. For all cases, the TRUCK model was used for HT market-penetration modeling. As described in Section 2.2.1, the baseline technology package for each size class represents No Program, and most vehicles are baseline vehicles (with the shares of vehicles with integrated start-generators [ISGs], plug-in hybrid electric vehicle [PHEVs], battery electric vehicles [BEVs], hydrogen fuel cell vehicles [FCVs], and natural gas vehicles and liquefied petroleum gas vehicles the same as in the AEO 2019 Reference Case [EIA 2019]). Market-penetration estimates are based on the time it takes for the fuel savings to offset the incremental cost of the technology - a calculation that depends on annual miles of travel. Therefore, fuel-saving technologies are adopted at a higher rate in applications with aboveaverage annual mileage. As a result, using a simple percentage of truck sales does not provide an accurate accounting of fuel consumption, so new-fleet fuel economy is calculated as a VMTweighted average.

As explained in Section 2.2.3, multiple powertrain technologies were modeled in four vehicle classes or segments:

- Class 7\&8 Sleeper Cab

- Class 7\&8 Day Cab

- Class $7 \& 8$ Vocational

- Class 4-6 Vocational

In addition, only technologies developed for diesel trucks in weight Classes 4-8 were analyzed. As a result, the sales of Class 4-8 gasoline trucks and all Class 3 trucks in the Program Success case remain the same as in the No Program case.

As described in Section 2.2.3, fuel prices were taken from the AEO 2019 Reference Case, except for hydrogen and electricity. Diesel was assumed to be readily available for all HTs, as were electricity and hydrogen for centrally refueled fleets. For non-centrally refueled fleets, electricity and hydrogen were assumed to be available at a fraction of public stations. This fraction was assumed to increase over time. For electric charging stations, this fraction was based on extrapolations of historical numbers of gasoline and public charging station counts from the Alternative Fuel Data Center, as described in Section 2.2.3. Historical station numbers for lightduty vehicle (LDV) stations were used because of lack of data or projections for charging stations for electric HTs. For hydrogen, the fraction was based on scenarios used in the LDV benefits analysis described in Section 2.1.2. The TRUCK penetration model uses fuel availability in calculating market penetration of FCVs and BEVs in centrally refueled fleets, by applying a factor to the market share of these choices (if they have sufficiently short payback time and, for 
BEVs, sufficient charge-depleting range). A side case, assuming no constraint related to fuel availability, was analyzed and is discussed in Section B.2.

Market penetration of each technology within each of the classes analyzed (including both centrally and non-centrally refueled fleets) is shown as a percentage of the VMT in Table B-1, and as shares of new vehicle sales in Table B-2.

TABLE B-1 HT Market-penetration Estimates for the Program Success Case, as Percentage of VMT by New Vehicles

\begin{tabular}{|c|c|c|c|c|}
\hline \multirow[b]{2}{*}{ Vehicle } & \multicolumn{4}{|c|}{$\%$ VMT by New Vehicles } \\
\hline & 2025 & 2030 & 2040 & 2050 \\
\hline \multicolumn{5}{|l|}{ Class $7 \& 8$ Sleeper Cab } \\
\hline Baseline & 32.9 & 2.5 & 1.8 & 1.9 \\
\hline Advanced conventional & 32.0 & 36.4 & 34.7 & 27.4 \\
\hline ISG & 30.4 & 36.3 & 34.5 & 27.2 \\
\hline HEV & 4.7 & 24.8 & 26.4 & 20.1 \\
\hline PHEV & 0.0 & 0.0 & 0.3 & 15.7 \\
\hline FCV & 0.0 & 0.0 & 2.3 & 7.7 \\
\hline \multicolumn{5}{|l|}{ Class $7 \& 8$ Day Cab } \\
\hline Baseline & 51.9 & 18.3 & 16.5 & 6.8 \\
\hline Advanced conventional & 24.5 & 41.0 & 30.0 & 24.4 \\
\hline ISG & 23.6 & 40.7 & 30.0 & 24.3 \\
\hline PHEV & 0.0 & 0.0 & 10.5 & 23.3 \\
\hline BEV & 0.0 & 0.0 & 0.0 & 2.4 \\
\hline FCV & 0.0 & 0.0 & 13.0 & 18.7 \\
\hline \multicolumn{5}{|l|}{ Class 8 Vocational } \\
\hline Baseline & 76.8 & 45.3 & 41.6 & 42.9 \\
\hline Advanced conventional & 7.8 & 17.3 & 17.9 & 13.2 \\
\hline ISG & 11.1 & 23.8 & 24.3 & 17.5 \\
\hline HEV & 4.4 & 13.1 & 12.9 & 9.7 \\
\hline PHEV & 0.0 & 0.5 & 3.1 & 9.3 \\
\hline BEV & 0.0 & 0.0 & 0.2 & 7.4 \\
\hline \multicolumn{5}{|l|}{ Class 4-6 vocational } \\
\hline Baseline & 84.7 & 41.6 & 1.0 & 0.4 \\
\hline Advanced conventional & 7.6 & 16.9 & 15.3 & 11.1 \\
\hline HEV & 7.4 & 18.3 & 21.6 & 15.7 \\
\hline PHEV & 0.0 & 3.3 & 11.5 & 18.0 \\
\hline BEV & 0.3 & 15.0 & 36.6 & 27.5 \\
\hline FCV & 0.0 & 5.0 & 14.0 & 27.2 \\
\hline
\end{tabular}


TABLE B-2 HT Market-penetration Estimates for the Program Success Case, as Percentage of New-vehicle Sales

\begin{tabular}{|c|c|c|c|c|}
\hline \multirow[b]{2}{*}{ Vehicle } & \multicolumn{4}{|c|}{$\%$ Sales of New Vehicles } \\
\hline & 2025 & 2030 & 2040 & 2050 \\
\hline \multicolumn{5}{|l|}{ Class $7 \& 8$ Sleeper Cab } \\
\hline Baseline & 36.5 & 6.3 & 5.3 & 5.4 \\
\hline Advanced conventional & 31.2 & 35.9 & 34.4 & 27.1 \\
\hline ISG & 28.9 & 35.6 & 34.0 & 26.8 \\
\hline HEV & 3.4 & 22.2 & 24.0 & 18.4 \\
\hline PHEV & 0.0 & 0.0 & 0.1 & 14.6 \\
\hline FCV & 0.0 & 0.0 & 1.9 & 7.6 \\
\hline \multicolumn{5}{|l|}{ Class $7 \& 8$ Day Cab } \\
\hline Baseline & 65.3 & 35.2 & 32.9 & 15.6 \\
\hline Advanced conventional & 17.8 & 32.6 & 25.6 & 20.0 \\
\hline ISG & 16.9 & 32.3 & 25.5 & 20.0 \\
\hline PHEV & 0.0 & 0.0 & 6.4 & 20.5 \\
\hline $\mathrm{BEV}$ & 0.0 & 0.0 & 0.0 & 4.4 \\
\hline FCV & 0.0 & 0.0 & 9.6 & 19.6 \\
\hline \multicolumn{5}{|l|}{ Class 8 Vocational } \\
\hline Baseline & 85.0 & 67.0 & 63.8 & 65.1 \\
\hline Advanced conventional & 5.8 & 10.2 & 11.1 & 7.9 \\
\hline ISG & 7.5 & 15.9 & 16.9 & 11.7 \\
\hline HEV & 1.7 & 6.8 & 7.2 & 5.1 \\
\hline PHEV & 0.0 & 0.1 & 0.9 & 5.3 \\
\hline $\mathrm{BEV}$ & 0.0 & 0.0 & 0.1 & 5.0 \\
\hline \multicolumn{5}{|l|}{ Class 4-6 vocational } \\
\hline Baseline & 95.0 & 63.1 & 1.2 & 0.2 \\
\hline Advanced conventional & 2.4 & 9.4 & 8.7 & 6.1 \\
\hline HEV & 2.4 & 10.6 & 14.7 & 10.3 \\
\hline PHEV & 0.0 & 0.9 & 5.9 & 13.9 \\
\hline $\mathrm{BEV}$ & 0.2 & 13.9 & 54.6 & 36.5 \\
\hline FCV & 0.0 & 2.1 & 14.9 & 33.0 \\
\hline
\end{tabular}

In Class 8 sleeper cab trucks, the diesel-powered alternative powertrains (advanced conventional, ISG, and HEV) show immediate high market penetration, as shown in Figure B-1, reaching $67 \%$ of VMT in 2025 and over $97 \%$ by 2030 . This penetration is due to the relatively small incremental costs as well as the high annual miles traveled for sleeper trucks, equating to a quick payback. Advanced conventional and ISG powertrains are very similar in both performance and cost, and therefore take an equal share of the alternative-powertrain market, while HEVs are slightly more expensive (less so as time progresses) and take a smaller share. PHEVs do not see significant adoption until after 2040, when they reach nearly $16 \%$ of VMT by 2050. FCVs are somewhat limited in this category, despite low incremental costs by the end of the analysis period, owing to more modest improvements in fuel economy and higher fuel prices relative to conventional diesel. 


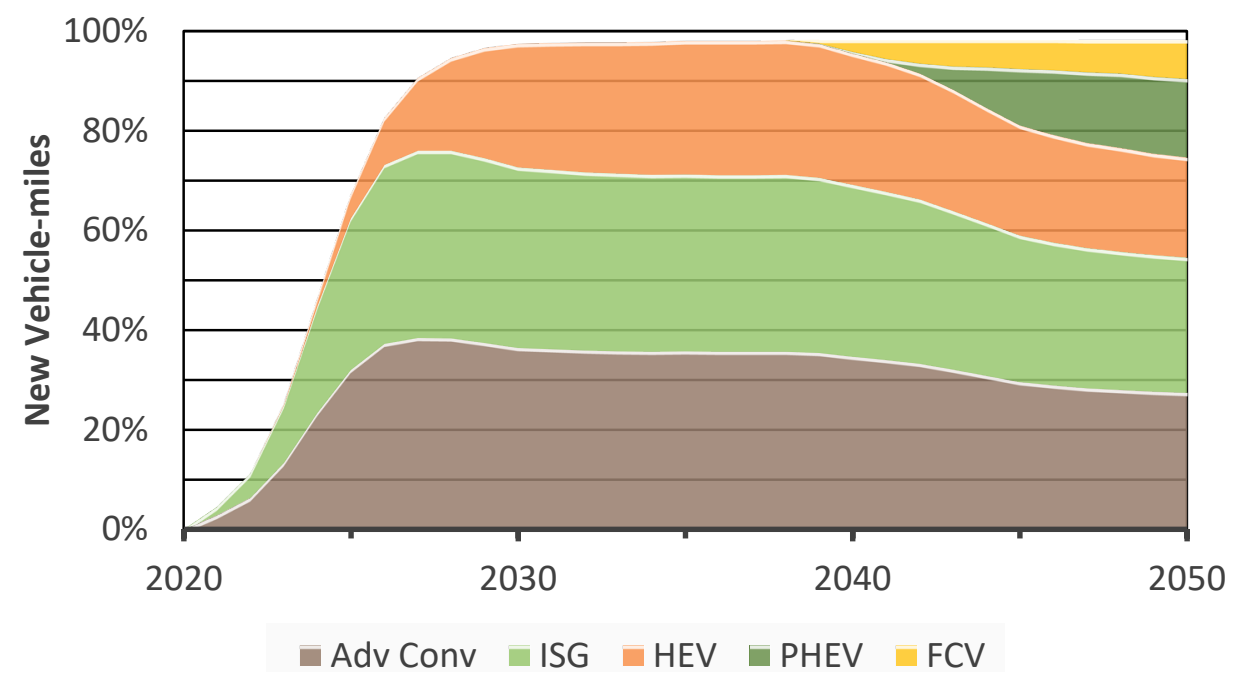

FIGURE B-1 Estimated Shares of VMT by New Class 8 Sleeper Cab Trucks by Powertrain Type for the Program Success Case

Class $7 \& 8$ day-cab trucks show a similar trend, as shown in Figure B-2, with dieselpowered alternative powertrains penetrating VMT quickly, reaching about $48 \%$ in 2025 and a peak of $82 \%$ around 2031 . The lower annual miles traveled, around 30\% lower than sleeper cabs, and correspondingly slower payback result in slightly lower adoption compared to sleeper cabs. PHEVs and FCVs begin to achieve significant shares around 2038 and together reach $42 \%$ of VMT by 2050. BEVs do not attain significant shares in this market, likely owing to range constraints in longer-distance uses where payback becomes attractive. In total, advanced vehicles account for $84 \%$ of sales and $93 \%$ of new vehicle-miles in 2050 .

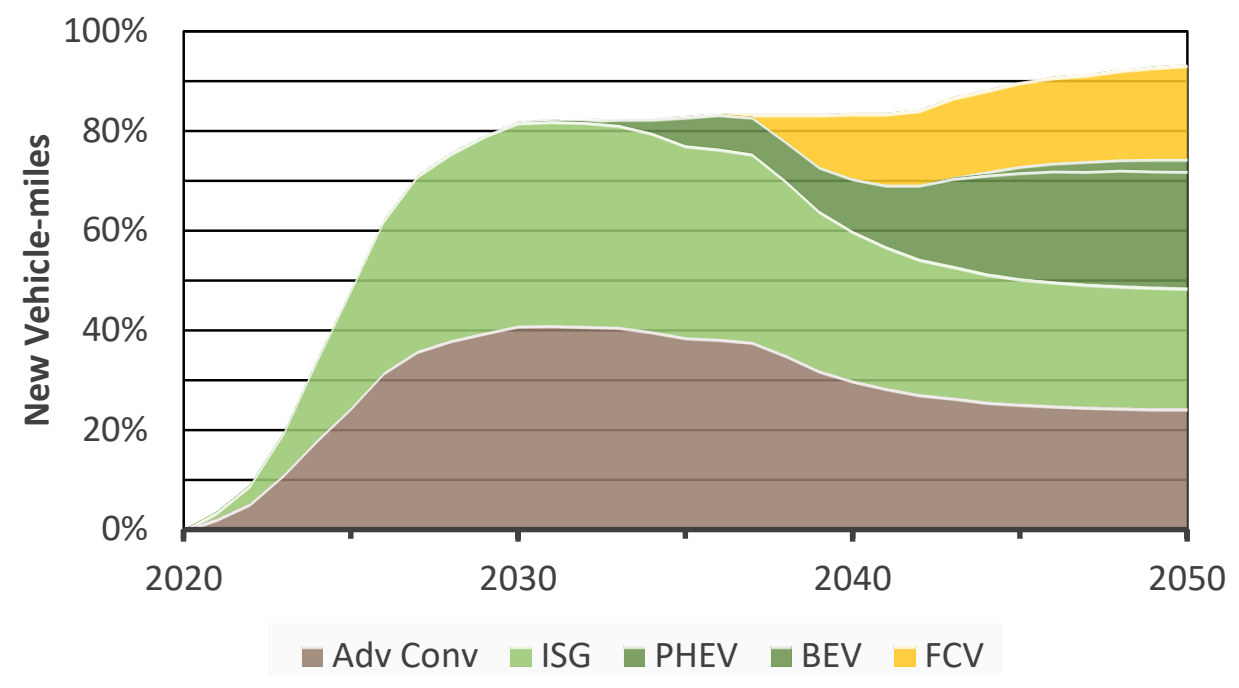

FIGURE B-2 Estimated Shares of VMT by New Class $7 \& 8$ Day-cab Trucks by Powertrain Type for the Program Success Case 
Penetration by advanced powertrains in Class $7 \& 8$ vocational trucks is lower, likely owing to the considerably lower annual miles traveled by trucks in this class $(75 \%$ lower than sleeper cabs and 65\% lower than day cabs). As shown in Figure B-3, the VMT shares for advanced conventional, ISG, and HEV powertrains grow rapidly through 2030, as seen with the other Class $7 \& 8$ segments. They achieve lower adoption compared to tractors, but together reach a maximum of 55\%. PHEVs and BEVs begin to gain VMT shares after 2035, but at a very slow rate. In total, advanced vehicles account for $35 \%$ of sales and $57 \%$ of new vehicle-miles in 2050 , with plug-in options accounting for $10 \%$ of sales and $17 \%$ of miles in 2050 .

The Class 4-6 results are markedly different from all three Class $7 \& 8$ markets. As shown in Figure B-4, Class 4-6 fleets adopt the diesel-based alternative powertrains (advanced conventional and HEV) at a much slower rate, reaching a maximum of almost $25 \%$ of the market and $39 \%$ of VMT at around 2035 and decreasing for the remainder of the modeling period. BEVs quickly penetrate, increasing to $55 \%$ of sales and $37 \%$ of VMT by 2037 . FCVs achieve a $15 \%$ share of sales over this same period, hold steady through 2041, and then grow rapidly to achieve a 33\% share by 2050 . Meanwhile, PHEVs grow slowly and attain a $14 \%$ share by 2050 . This pattern is likely due to the short payback period enabled by rapid decreases in battery incremental costs. As costs of batteries, fuel cells, and hydrogen storage decrease, FCVs become cheaper than the base vehicle by 2034, and BEVs are the next cheapest alternative by 2036 . The apparent FCV price advantage is offset by limited fuel availability. In total, advanced vehicles account for over $99 \%$ of both sales and new vehicle-miles in 2050 .

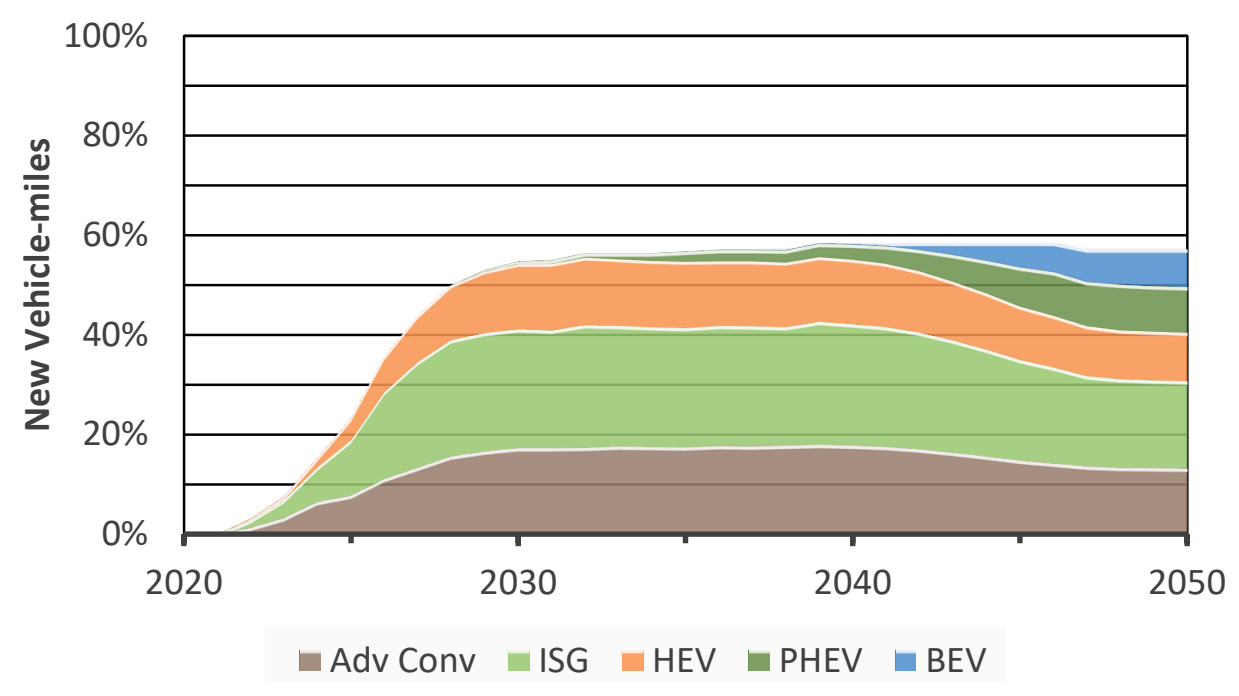

FIGURE B-3 Estimated Shares of VMT by New Class $7 \& 8$ Vocational Vehicles by Powertrain Type for the Program Success Case 


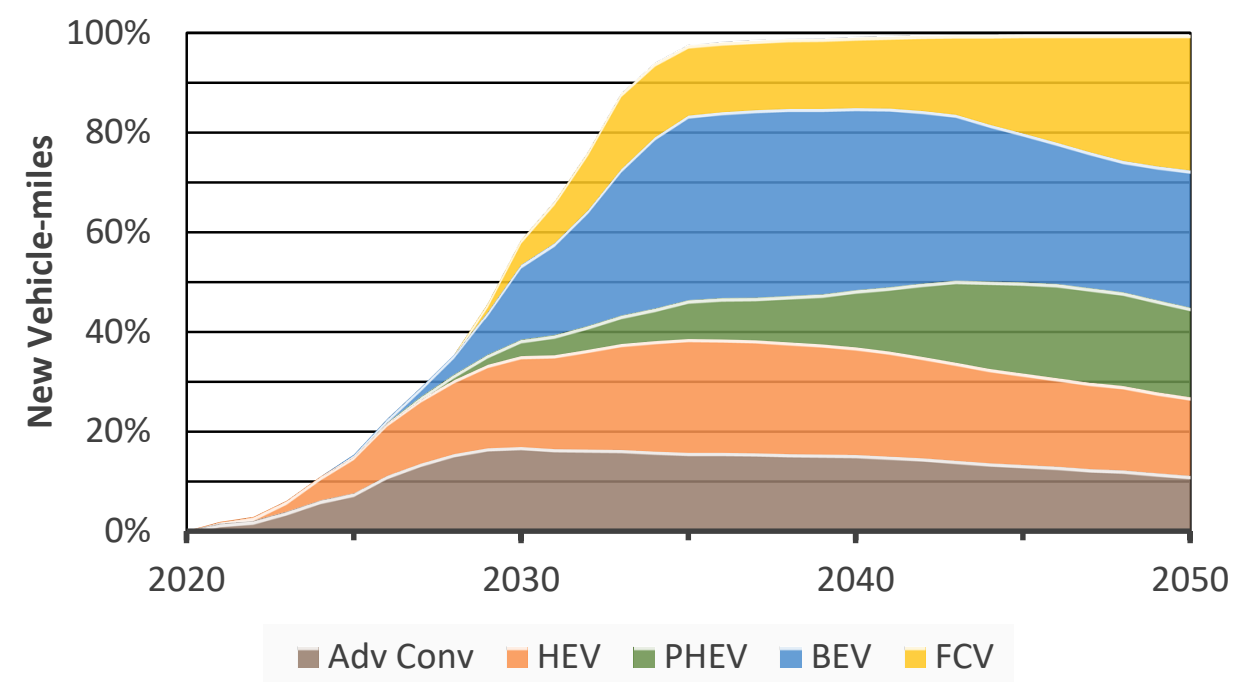

FIGURE B-4 Estimated Shares of VMT by New Class 4-6 Vocational Vehicles by Powertrain Type for the Program Success Case

\section{B.2 HEAVY-TRUCK MARKET-PENETRATION SIDE CASE}

To assess the sensitivity of HT market modeling results to assumptions about future availability of hydrogen and electricity, a side case was run, keeping all inputs the same as in the Program Success case except for availability of hydrogen and electricity to non-centrally refueled fleets. For these fleets, the fuel availability constraint was removed. (Note that in the Program Success case, all fuels were assumed to be fully available to centrally refueled fleets). Thus, all fuels were assumed to be fully available to all fleets, as could be the case if fueling infrastructure were built out concurrently with PEV and FCV market adoption.

Market penetration of each technology within each of the classes analyzed (including both centrally and non-centrally refueled fleets) is shown as a percentage of the VMT in Table B-3, and as shares of new-vehicle sales in Table B-4. 
TABLE B-3 HT Market-penetration Estimates for the Full Fuel Availability Side Case, as Percentage of VMT by New Vehicles

\begin{tabular}{|c|c|c|c|c|}
\hline \multirow[b]{2}{*}{ Vehicle } & \multicolumn{4}{|c|}{$\%$ VMT by New Vehicles } \\
\hline & 2025 & 2030 & 2040 & 2050 \\
\hline \multicolumn{5}{|l|}{ Class $7 \& 8$ Sleeper Cab } \\
\hline Baseline & 32.9 & 2.5 & 1.8 & 1.8 \\
\hline Advanced conventional & 32.0 & 36.4 & 29.8 & 22.9 \\
\hline ISG & 30.4 & 36.3 & 29.6 & 22.7 \\
\hline HEV & 4.7 & 24.8 & 22.5 & 16.8 \\
\hline PHEV & 0.0 & 0.0 & 0.2 & 13.1 \\
\hline FCV & 0.0 & 0.0 & 16.1 & 22.6 \\
\hline \multicolumn{5}{|l|}{ Class 7\&8 Day Cab } \\
\hline Baseline & 51.9 & 18.3 & 16.5 & 1.9 \\
\hline Advanced conventional & 24.5 & 41.0 & 26.2 & 22.8 \\
\hline ISG & 23.6 & 40.7 & 26.2 & 22.7 \\
\hline PHEV & 0.0 & 0.0 & 9.2 & 21.9 \\
\hline BEV & 0.0 & 0.0 & 0.0 & 2.6 \\
\hline FCV & 0.0 & 0.0 & 21.9 & 28.1 \\
\hline \multicolumn{5}{|l|}{ Class 8 Vocational } \\
\hline Baseline & 76.8 & 45.3 & 41.6 & 42.9 \\
\hline Advanced conventional & 7.8 & 17.3 & 17.8 & 13.2 \\
\hline ISG & 11.1 & 23.8 & 24.3 & 17.5 \\
\hline HEV & 4.4 & 13.1 & 12.9 & 9.7 \\
\hline PHEV & 0.0 & 0.5 & 3.1 & 9.3 \\
\hline BEV & 0.0 & 0.0 & 0.3 & 7.4 \\
\hline \multicolumn{5}{|l|}{ Class 4-6 vocational } \\
\hline Baseline & 84.6 & 37.5 & 0.0 & 0.0 \\
\hline Advanced conventional & 7.4 & 15.6 & 12.8 & 11.6 \\
\hline HEV & 7.3 & 16.9 & 17.8 & 16.1 \\
\hline PHEV & 0.0 & 2.9 & 9.6 & 18.3 \\
\hline BEV & 0.6 & 18.6 & 26.4 & 23.8 \\
\hline FCV & 0.0 & 8.4 & 33.4 & 30.2 \\
\hline
\end{tabular}


TABLE B-4 HT Market-penetration Estimates for the Full Fuel Availability Side Case, as Percentage of New-vehicle Sales

\begin{tabular}{|c|c|c|c|c|}
\hline \multirow[b]{2}{*}{ Vehicle } & \multicolumn{4}{|c|}{$\%$ Sales of New Vehicles } \\
\hline & 2025 & 2030 & 2040 & 2050 \\
\hline \multicolumn{5}{|l|}{ Class 7\&8 Sleeper Cab } \\
\hline Baseline & 36.5 & 6.3 & 5.3 & 5.4 \\
\hline Advanced conventional & 31.2 & 35.9 & 30.0 & 22.6 \\
\hline ISG & 28.9 & 35.6 & 29.6 & 22.4 \\
\hline HEV & 3.4 & 22.2 & 20.8 & 15.3 \\
\hline PHEV & 0.0 & 0.0 & 0.1 & 12.1 \\
\hline FCV & 0.0 & 0.0 & 14.1 & 22.2 \\
\hline \multicolumn{5}{|l|}{ Class 7\&8 Day Cab } \\
\hline Baseline & 65.3 & 35.2 & 32.9 & 7.2 \\
\hline Advanced conventional & 17.8 & 32.6 & 22.2 & 18.9 \\
\hline ISG & 16.9 & 32.3 & 22.2 & 18.9 \\
\hline PHEV & 0.0 & 0.0 & 5.5 & 19.6 \\
\hline BEV & 0.0 & 0.0 & 0.0 & 4.6 \\
\hline FCV & 0.0 & 0.0 & 17.1 & 30.6 \\
\hline \multicolumn{5}{|l|}{ Class 8 Vocational } \\
\hline Baseline & 85.0 & 67.0 & 63.8 & 65.1 \\
\hline Advanced conventional & 5.8 & 10.2 & 11.1 & 7.9 \\
\hline ISG & 7.5 & 15.9 & 16.9 & 11.7 \\
\hline HEV & 1.7 & 6.8 & 7.2 & 5.1 \\
\hline PHEV & 0.0 & 0.1 & 0.9 & 5.3 \\
\hline BEV & 0.0 & 0.0 & 0.1 & 5.0 \\
\hline \multicolumn{5}{|l|}{ Class 4-6 vocational } \\
\hline Baseline & 95.0 & 59.5 & 0.0 & 0.0 \\
\hline Advanced conventional & 2.3 & 8.9 & 7.1 & 6.1 \\
\hline $\mathrm{HEV}$ & 2.3 & 10.2 & 11.7 & 10.3 \\
\hline PHEV & 0.0 & 0.8 & 4.7 & 13.6 \\
\hline BEV & 0.4 & 17.3 & 36.9 & 34.0 \\
\hline FCV & 0.0 & 3.4 & 39.6 & 35.9 \\
\hline
\end{tabular}

Shares of VMT by new vehicles for each of the four market segments in the side case are shown in Figure B-5. VMT shares in Figure B-5 show a rapid increase after 2035 in adoption of FCVs in Class 8 sleeper cabs (a), Class $7 \& 8$ day cabs (b), and Class 4-6 vocational vehicles (d). FCVs were not modeled in Class 7 Vocational trucks. Shares of PEVs are less influenced by increased fuel availability than FCVs. This side case shows that future adoption of FCVs in the HT market is uncertain and depends on availability of hydrogen in segments in which FCVs are most competitive, Class 4-6 in particular. If future hydrogen infrastructure is built out more or less rapidly than assumed in the Program Success case, then more or fewer FCVs may be adopted in non-centrally refueled fleets than reported in Section 2, and resulting benefits could be somewhat different from those estimated. Such differences in this analysis are significant only 
in years after 2035. However, since Class 4-6 vehicles account for a modest fraction of fuel consumed on-road, the influence of hydrogen availability is not large enough to change the main conclusion of the analysis, and given sufficient availability of hydrogen at public fueling stations, FCVs can contribute to reducing petroleum use and GHG emissions.
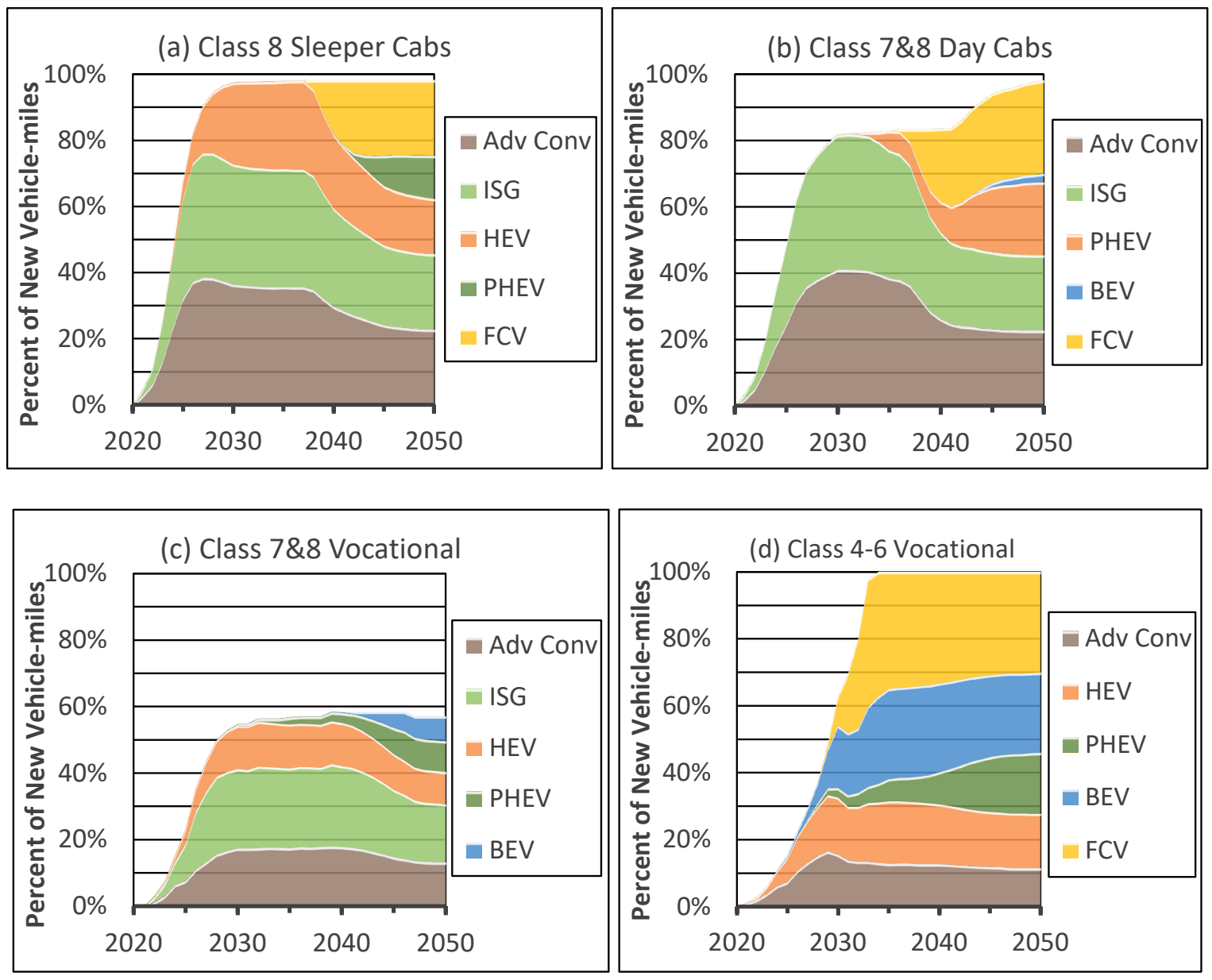

FIGURE B-5 Estimated Shares of VMT by New (a) Class 8 Sleeper-cab Trucks, (b) Class $7 \& 8$ Day-cab Trucks, (c) Class $7 \& 8$ Single-unit Vocational Trucks, and (d) Class 4-6 Vocational Vehicles, for the Side Case Assuming No Constraints from Fuel Availability.

\section{B.3 AVERAGE HT FUEL ECONOMY}

Averages of new-vehicle fleet fuel economy values for HTs are shown in Figure B-6 for the Program Success and No Program cases. For stock modeling, powertrains not included in the market adoption model (e.g., gasoline and natural gas) are assumed to maintain AEO 2019 Reference Case (EIA 2019) sales. Fleet averages (of new vehicles) shown in Figure B-6 are mileage-weighted values and include these additional powertrains. As a result of DOE-supported technologies, the fuel economy of the fleet of new Class $7 \& 8$ trucks increases by $21 \%$ to $32 \%$ by 
2050 and the fuel economy of all Class $4-6$ trucks increases by $52 \%$ because of high market penetration of electrified powertrains, as shown in Figure B-7.

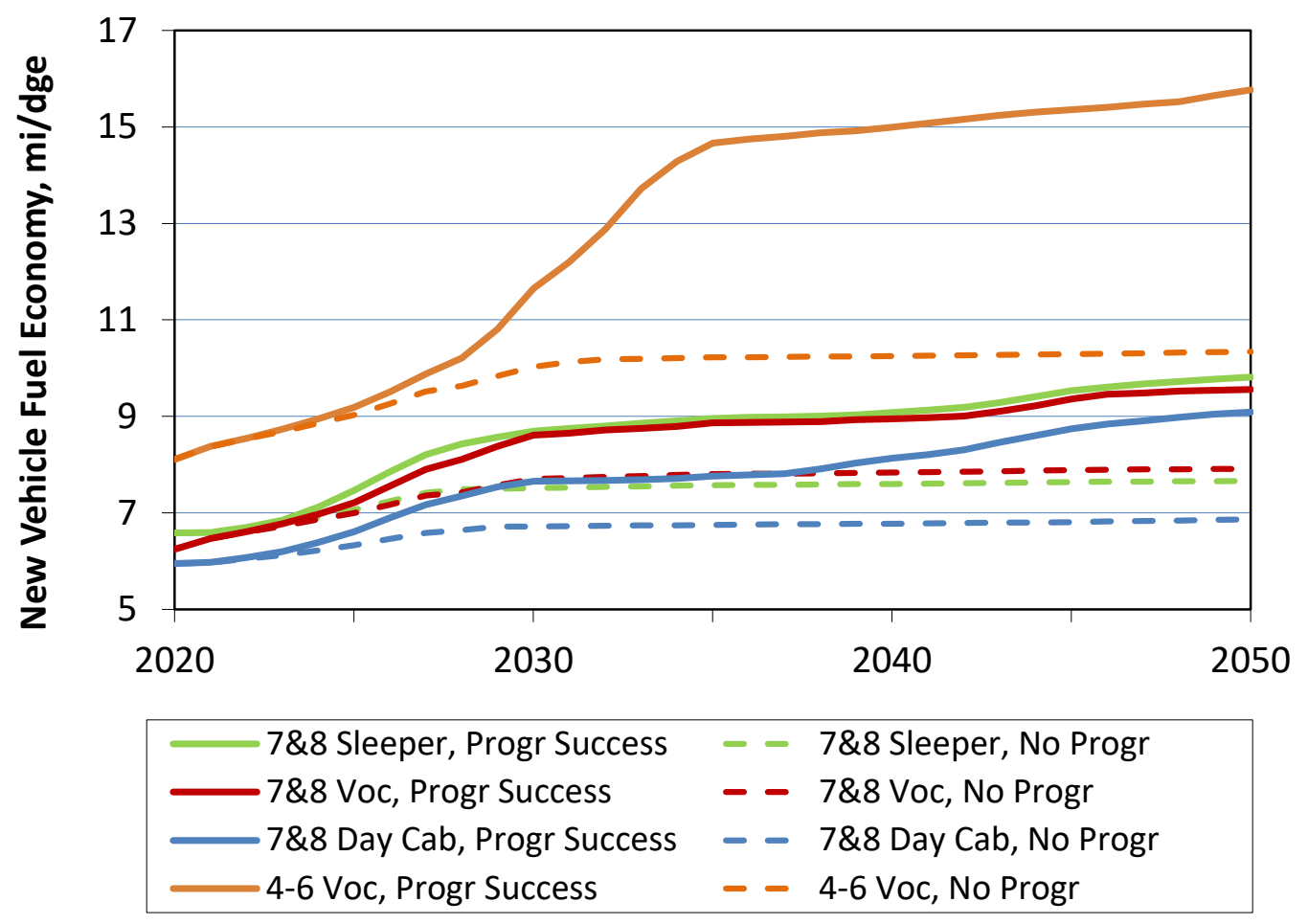

FIGURE B-6 Fleet-averaged Fuel Economy of New HTs for the No Program (dashed lines) and Program Success (solid lines) Cases 


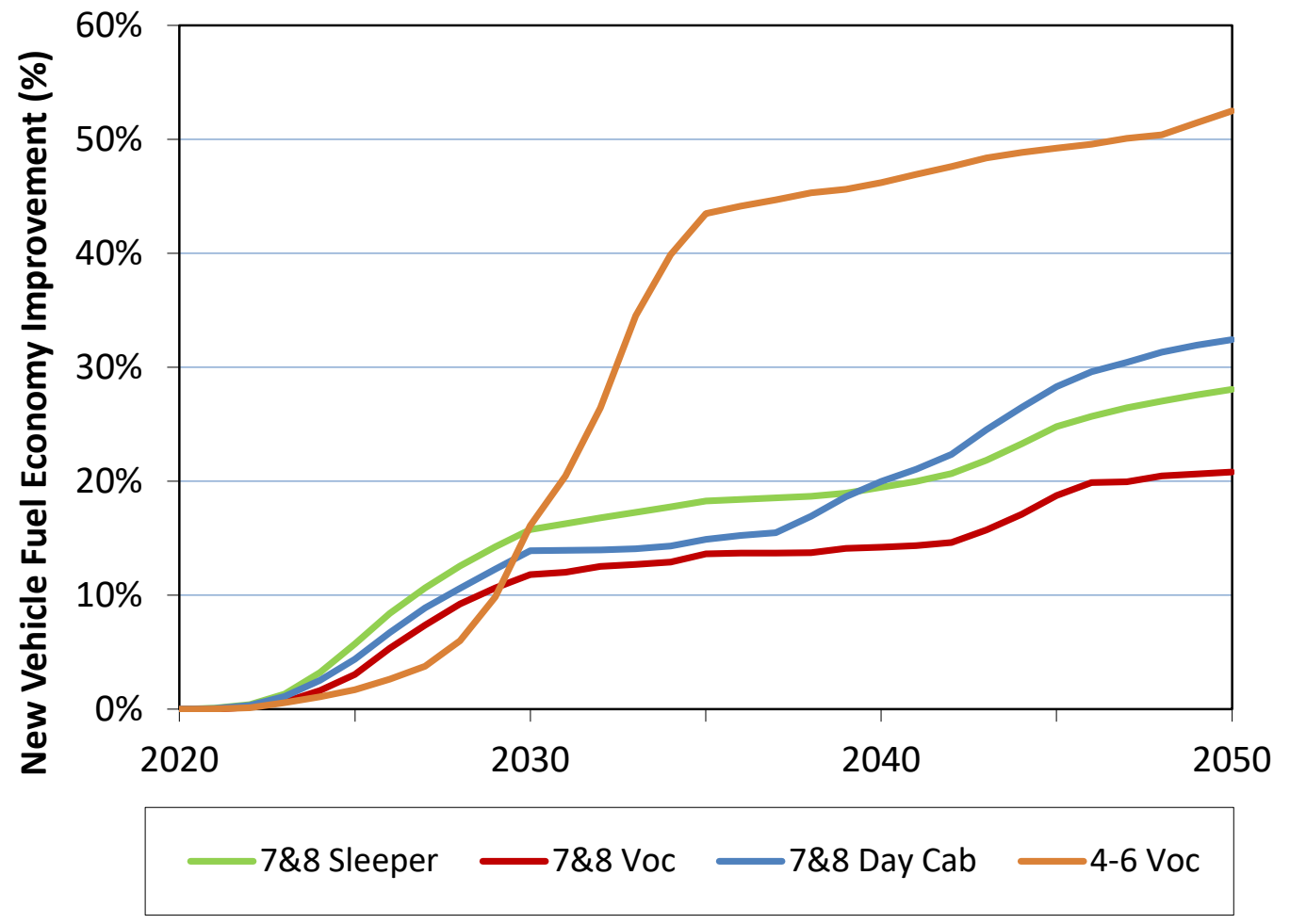

FIGURE B-7 Increase in New-fleet Fuel Economy, Program Success Case vs. No Program Case

The average fuel economies of the on-road stock of HTs of each range of size class analyzed are shown in Figure B-8. The on-road fuel economy increases for each size class range as DOE-supported technologies penetrate the on-road stock. The fuel economy of the entire onroad HT fleet, including all fuel types, increases by 8\%, from 8.4 mpgde to 9.1 mpgde, in 2035 and by $20 \%$, from 9.2 mpgde to 11.0 mpgde, in 2050 . 


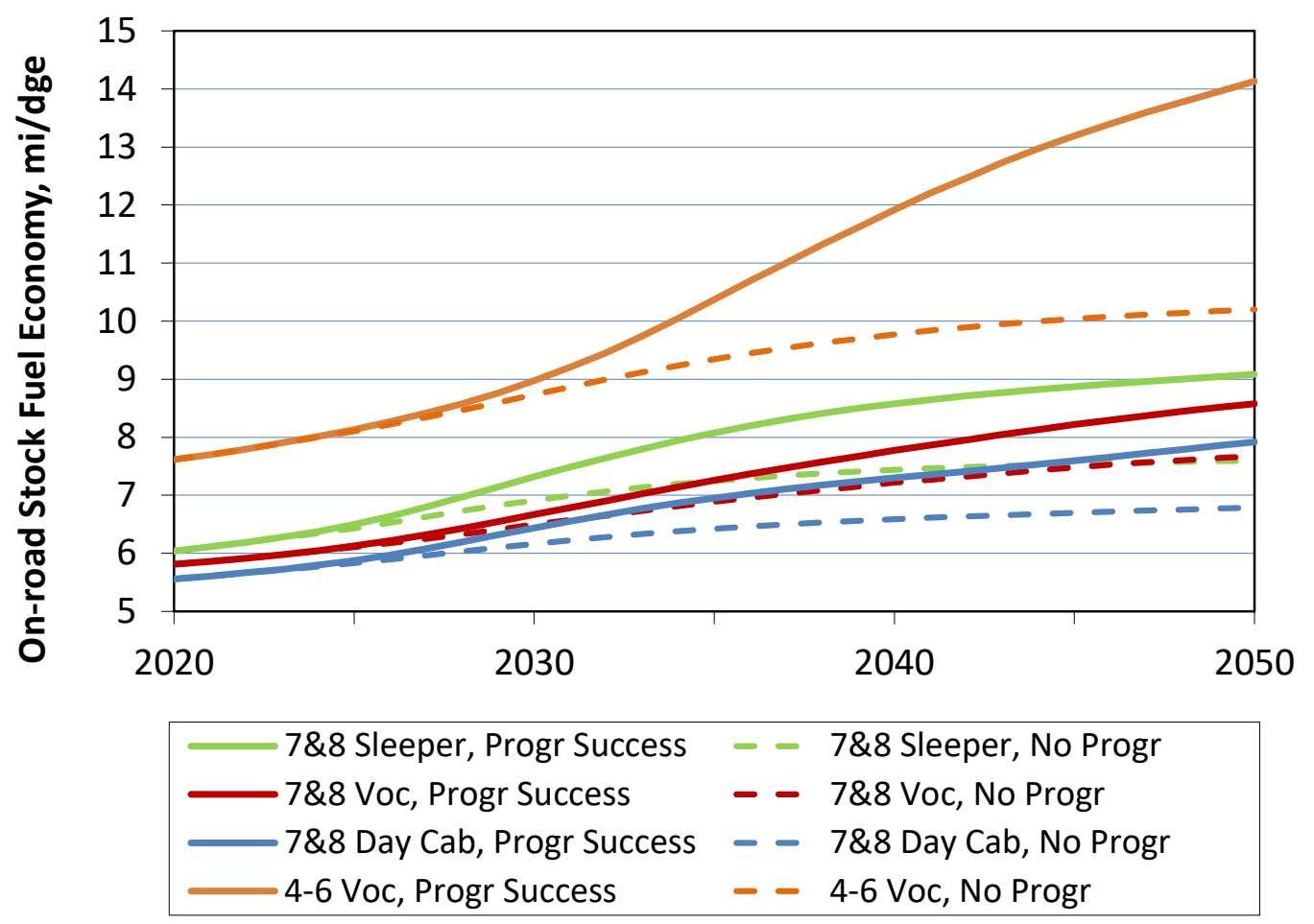

FIGURE B-8 Average Fuel Economy of On-road Stock of HTs for the No Program (dashed lines) and Program Success (solid lines) Cases

\section{B.4 REFERENCES}

EIA (U.S. Energy Information Administration), 2019, Annual Energy Outlook 2019: With Projections to 2050, Office of Integrated Analysis and Forecasting, Energy Information Administration, U.S. Department of Energy, Washington, D.C., https://www.eia.gov/outlooks/archive/aeo19/pdf/aeo2019.pdf, accessed July 27, 2020. 
This page left intentionally blank. 



\section{Argonne 4}

\section{Energy Systems Division}

Argonne National Laboratory

9700 South Cass Avenue, Bldg. 362

Lemont, IL 60439-4832

www.anl.gov 